\title{
Graphical Abstract
}

\section{Synthesis and photolytic evaluation of a nitroindoline-caged glycine with a side chain of high negative charge for use in neuroscience}

George Papageorgiou, ${ }^{\mathrm{a}^{*}}$ Marco Beato ${ }^{\mathrm{b}}$ and David Ogden ${ }^{\mathrm{c}}$

a. MRC National Institute for Medical Research, The Ridgeway, Mill Hill, London NW7 1AA, UK

b. Department of Neuroscience, Physiology and Pharmacology, University College London, Gower Street, London WC1E 6BT, UK

c. CNRS Unité 8118, Université Paris Descartes, 75006 Paris, France<smiles></smiles><smiles>O=CO</smiles><smiles>[NH3+]CC(=O)O[Na]</smiles> 


\title{
Synthesis and photolytic evaluation of a nitroindoline-caged glycine with a side chain of high negative charge for use in neuroscience $^{\dagger}$
}

\author{
George Papageorgiou, ${ }^{\mathrm{a}^{*}}$ Marco Beato ${ }^{\mathrm{b}}$ and David Ogden ${ }^{\mathrm{c}}$
}

a. MRC National Institute for Medical Research, The Ridgeway, Mill Hill, London NW7 1AA, UK

b. Department of Neuroscience, Physiology and Pharmacology, University College

London, Gower Street, London WC1E 6BT, UK

c. CNRS Unité 8118, Université Paris Descartes, 75006 Paris, France

\begin{abstract}
A photolabile precursor of the neuroinhibitory amino acid glycine has been synthesised with two phosphate groups attached to the indoline nucleus at a 4alkoxy substituent. In common with the photochemical properties of other 1-acyl-7nitroindolines, this releases glycine on a sub- $\mu$ s time scale upon irradiation with nearUV light. The synthetic route previously developed for the preparation of the GABA analogue required some modifications because of the greater hydrolytic sensitivity of the glycine compound. The phosphorylation method used here could be beneficial to the synthesis of other nitroindoline-caged amino acids, especially the related caged GABA derivative. Glycine released by laser photolysis on spinal cord neurons generated fast-rising responses and the pharmacological properties of the reagent are such that it is useful for physiological experiments.
\end{abstract}




\section{Introduction}

The technique of liberating biologically active compounds from photolabile precursors, upon brief irradiation with near-UV light is a valuable tool for studies of biological processes. The method relies on the availability of suitable reagents, widely known as 'caged' compounds and their syntheses and applications are described in reviews. ${ }^{1}$ These reagents must satisfy a number of prerequisites such as solubility and stability in aqueous media, high purity and pharmacological inertness prior to photolysis, rapid and efficient photolysis at neutral $\mathrm{pH}$ followed by fast dark reactions after photolysis, and no release of toxic by-products after photocleavage. Failure to fulfil any one of the above criteria usually renders a caged reagent inadequate for application in biological systems.

During the last decade we have produced a number of 7-nitroindoline-caged neuroactive amino acids, including L-glutamate $\mathbf{1}^{2}$ and $2,{ }^{3} \gamma$-aminobutyrate (GABA) 3 and glycine $4,{ }^{4}$ L-aspartate $5,{ }^{5}$ and L-alanine $\mathbf{6},{ }^{6}$ which have been applied in various biological systems. Detailed pharmacological evaluation has found that caged glutamates $\mathbf{1}$ and $\mathbf{2}$ do not bind to glutamergic receptors prior to photolysis and are therefore suitable reagents for investigations of synaptic transmission. ${ }^{4,5,7}$ They fulfil all the above criteria to a satisfactory extent, they are now commercially available and have been extensively applied in neuroscience. ${ }^{8}$ In contrast, caged GABA 3 and caged glycine $\mathbf{4}$ were found to bind to their respective ionotropic GABA or glycine receptors

\footnotetext{
* Keywords: Photolysis; Caged Compounds; Nitroindolines; Phosphorylation

${ }^{\dagger}$ The work described here is, in part, the subject of patent applications US Appl. 11/507961 and EP Appl. 06254350.4

*Corresponding author. Tel.: +44 208816 2407; fax: +44 208906 4477;

e-mail address: gpapage@ nimr.mrc.ac.uk
} 
on neuronal cells prior to photolysis, blunting the response to the photolyticallyreleased amino acid. ${ }^{4,7} \mathrm{~A}$ separate investigation has indicated that neither caged glycine 4 nor caged L-aspartate 5 inhibit the NMDA receptor, suggesting that reagent 4 might have useful application in studies of the effects of co-agonist binding to NMDA receptors. ${ }^{5}$ Photolytic release of L-alanine from 6 has enabled the observation of alanine-induced pre-steady-state currents of three different neutral amino acid transporters. $^{6}$<smiles>[R]c1cc([N+](=O)[O-])c2c(c1[R])CCN2C(=O)CC[C@H](N)C(=O)[O-]</smiles><smiles>[R]C(=O)N1CCc2cc(CC(=O)O)cc([N+](=O)[O-])c21</smiles>

$$
\begin{array}{ll}
\mathbf{1} \mathrm{R}^{1}=\mathrm{CH}_{2} \mathrm{CO}_{2} \mathrm{Me}, \mathrm{R}^{2}=\mathrm{H} & \mathbf{3} \mathrm{R}^{1}=\mathrm{Me}, \mathrm{R}^{2}=\left(\mathrm{CH}_{2}\right)_{3} \mathrm{NH}_{3} \\
\mathbf{2} \mathrm{R}^{1}=\mathrm{H}, \mathrm{R}^{2}=\mathrm{OMe} & \mathbf{4} \mathrm{R}^{1}=\mathrm{H}, \mathrm{R}^{2}=\mathrm{CH}_{2} \mathrm{NH}_{3}
\end{array}
$$<smiles>CC(=O)Cc1cc2c(c([N+](=O)[O-])c1)N(C(=O)CC(N)C(N)=O)CC2</smiles>

5<smiles>COc1ccc([N+](=O)[O-])c2c1CCN2C(=O)[C@H](C)N</smiles>

6

Photolysis of these reagents in aqueous solution proceeds with stoichiometric release of the amino acid, accompanied by the corresponding nitrosoindole by-product as shown in Scheme 1. A study of the photolysis mechanism ${ }^{9}$ of 1-acyl-7-nitroindolines in aqueous solution determined the release rate of the amino acid as $\sim 5 \times 10^{6} \mathrm{~s}^{-1}$ at ambient temperature, corresponding to a half-life of $\sim 150$ ns which is sufficiently rapid for mimicking biological processes. 

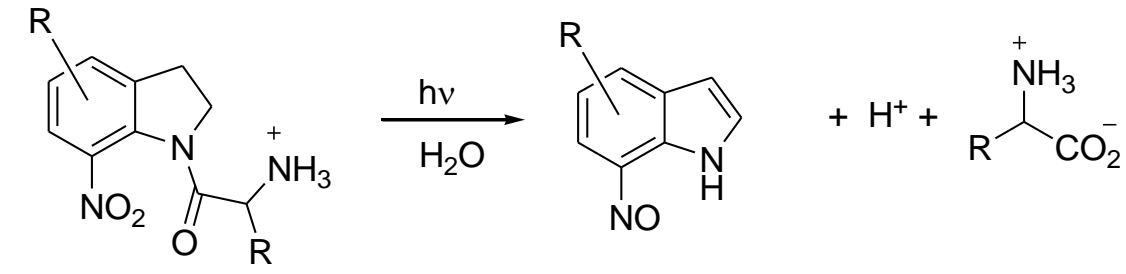

Scheme 1. Photocleavage reaction of 7-nitroindoline-caged amino acids in aqueous solution.

The advantageous photochemical properties and hydrolytic stability of 1-acyl-7nitroindolines motivated us to seek means of eliminating or at least suppressing the adverse pharmacological properties of $\mathbf{3}$ and we have previously reported the synthesis and photochemical evaluation of the modified caged GABA reagent $7 .^{10}$ The incorporation of a high concentration of negative charge close to the nitroindoline nucleus did not affect its photochemical properties. Furthermore, the structure retained the advantages of hydrolytic stability of the cage and its fast and efficient photorelease at near-UV and $405 \mathrm{~nm}$ wavelengths, but brought about a large reduction in the interaction of 7 with $\mathrm{GABA}_{\mathrm{A}}$ receptors. ${ }^{11 \mathrm{a}}$ Further detailed neurophysiological investigations $^{11 \mathrm{~b}}$ revealed the existence of a new class of miniature currents ("preminis") in developing interneurons that reflect the activation of presynaptic $\mathrm{GABA}_{\mathrm{A}}$ receptors following random vesicular release.

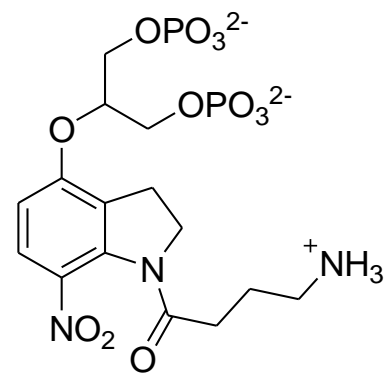

7

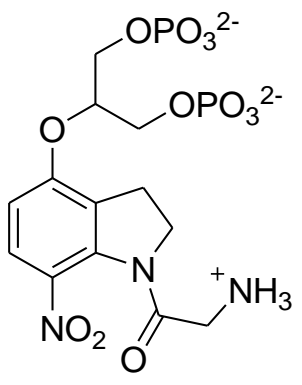

8

The successful reduction of adverse pharmacological properties of 7 prior to photolysis opened the possibility that the same strategy might be applied to the 
glycine analogue 8. Various caged glycine derivatives have been reported by other workers ${ }^{12}$ but have suffered from problems of instability or inadequate photolytic efficiency. We had anticipated that synthesis of the diphosphate nitroindoline (DPNI) glycine $\mathbf{8}$ would closely follow the route described for 7 . In the event, a number of modifications were required, in part because of greater hydrolytic sensitivity of the amide bond in the glycine series of precursors. In addition, the method for introduction of the two phosphate groups was substantially improved over that previously described in the synthesis of 7. In the course of developing the synthesis, we also prepared the 4-methoxy compound $\mathbf{1 5}$ and in the process obtained some further insight into side reactions that occurred during nitration reactions of $\mathrm{N}$ acylindolines.

\section{Results and discussion}

In our previous investigations ${ }^{10}$ of a synthetic route to 7 , we had found that di-Boc protection of the amino group in a GABA precursor had been ineffective in avoiding side reactions at this centre, although the same protection strategy had been effective for amino groups in precursors to 4-methoxy-7-nitroindoline derivatives of Lglutamate, ${ }^{13}$ and L-alanine. ${ }^{6}$ For the eventual successful synthesis of $\mathbf{7}$, the problem was avoided by masking the amino group as an azide that was converted to an amine at a late stage of the synthesis. Nevertheless, in view of the successful application of the di-Boc protection strategy for synthesis of L-alanine, we felt it was worthwhile to test the same methodology here. Using the 4-methoxy system, the route shown in Scheme 2 gave the di-Boc precursor 10. Homogeneous nitration, as used by us previously for related nitrations, ${ }^{3 b, 6,13}$ gave a mixture in which the major component was the $N$-nitro species $\mathbf{1 1}$, isolated as a crystalline solid and characterised by ${ }^{1} \mathrm{H}$ 
NMR spectroscopy and elemental analysis (see Supplementary data). Although 5- and 7-mononitro isomers were also present in the reaction products, the substantial formation of $\mathbf{1 1}$ made this route unacceptable. It now appears that both steric and electronic effects are important in the ability of the double Boc protection to limit unwanted $N$-nitration, and we therefore returned to the azide strategy used for 7 .

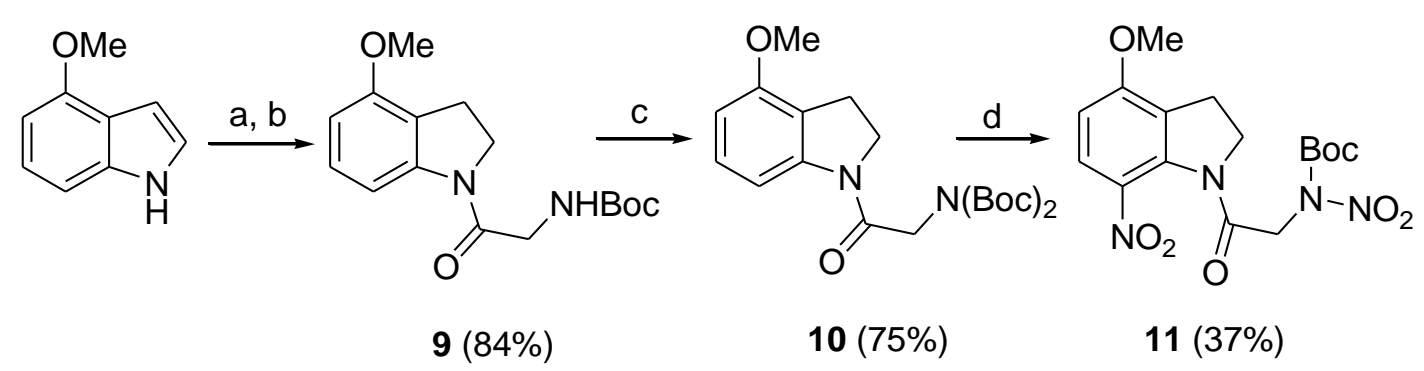

Scheme 2. Reagents: (a) $\mathrm{NaBH}_{3} \mathrm{CN}-\mathrm{AcOH}$; (b) $\mathrm{EDC}-\mathrm{HO}_{2} \mathrm{CCH}_{2} \mathrm{NHBoc}-\mathrm{MeCN}$; (c) $(\mathrm{Boc})_{2} \mathrm{O}-\mathrm{Et}_{3} \mathrm{~N}-\mathrm{DMAP}-\mathrm{CH}_{2} \mathrm{Cl}_{2}$; (d) $\mathrm{Cu}\left(\mathrm{NO}_{3}\right)_{2}-\mathrm{Ac}_{2} \mathrm{O}-\mathrm{CH}_{2} \mathrm{Cl}_{2}$.

Given the somewhat unpredictable outcome of results with only minor changes in structure, we first tested the azide route by preparing the methoxynitroindoline-caged glycine 15, as shown in Scheme 3, both to validate the individual steps and to have a sample of $\mathbf{1 5}$ available for pharmacological testing in comparison with our intended target compound 8. Only two points of Scheme 3 deserve specific comment. First, the nitration of the azidoacetylindoline $\mathbf{1 3}$ was carried out using a minor modification of a reported procedure ${ }^{14}\left(\mathrm{NaNO}_{3}\right.$ in place of $\left.\mathrm{LiNO}_{3}\right)$ in which scandium triflate acts as a catalyst for nitration. In practice, for this substrate there was no advantage in yield or regioselectivity over our previous claycop-mediated nitration procedure, ${ }^{3 \mathrm{~b}}$ but the scandium triflate procedure was investigated as an alternative because of difficulties encountered during the synthesis of $\mathbf{8}$ (see below) and because we had previously found that the claycop procedure was ineffective with indolines bearing a bulky substituent at the 4-position. ${ }^{10}$ The second point of note relates to the Staudinger 
reduction of the azide $\mathbf{1 4}$ that was carried out in aqueous DMF, as had been done at the final stage in synthesis of $\mathbf{8}$. In the latter case the initial product isolated had been an iminophosphorane, which required mild but prolonged acid treatment $(\mathrm{pH} 1$ at room temperature overnight) to release the required amine. ${ }^{10}$ In contrast, the reduction of $\mathbf{1 4}$ under the same conditions gave the amine directly upon work-up of the reaction mixture. As discussed below, the susceptibility to hydrolysis of the initial iminophosphorane product is remarkably idiosyncratic.

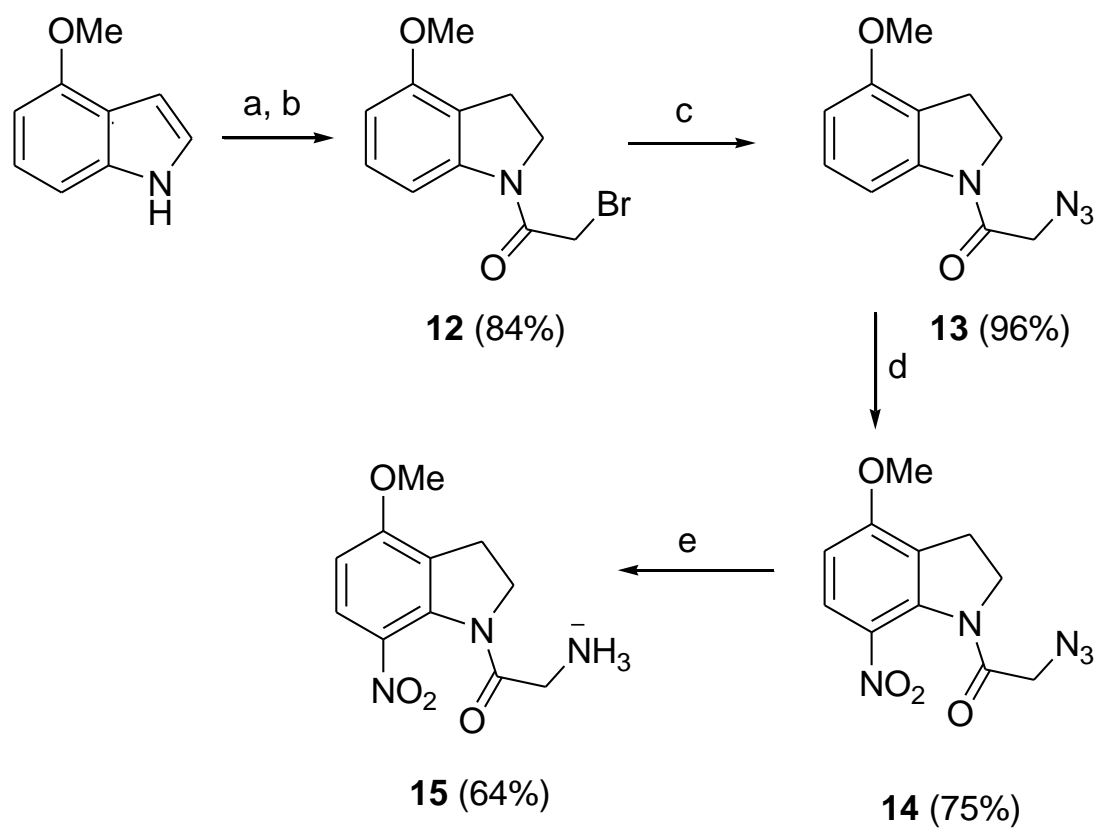

Scheme 3. Reagents: (a) $\mathrm{NaBH}_{3} \mathrm{CN}-\mathrm{AcOH}$; (b) $\mathrm{EDC}-\mathrm{BrCH}_{2} \mathrm{CO}_{2} \mathrm{H}-\mathrm{MeCN}$; (c) $\mathrm{NaN}_{3}-\mathrm{DMF}$; (d) $\mathrm{NaNO}_{3}-\mathrm{Ac}_{2} \mathrm{O}-\mathrm{Sc}(\mathrm{OTf})_{3}-\mathrm{MeCN}$; (e) $\mathrm{PPh}_{3}-$ aq. DMF.

With preparation of $\mathbf{1 5}$ readily achieved, we returned to the synthesis of $\mathbf{8}$ and, following similar methods to those in Scheme 3, readily obtained the azide $\mathbf{1 9}$ (Scheme 4). However, upon very brief alkaline treatment ( $25 \mathrm{mM} \mathrm{NaOH}$ for $2 \mathrm{~min}$ ) which was intended to remove the acetate groups, a mixture of products was detected by TLC and UV-vis spectroscopy that indicated significant hydrolysis of the amide linkage had taken place. This contrasts with experience in the synthesis of the caged 
GABA 7, where hydrolysis of the corresponding acetates was readily achieved under very similar conditions, without detectable amide hydrolysis. Electron-withdrawal by the $\alpha$-azido substituent evidently makes the azidoacetyl amide bond much more sensitive to base hydrolysis and we subsequently found that the amide bond was $\sim 10 \%$ hydrolysed at $\mathrm{pH} 7.0$ overnight at room temperature (see details in Supplementary Data).<smiles>CC(=O)OCC(COC(C)=O)Oc1cccc2[nH]c(C)cc12</smiles>

16<smiles>CC(=O)OCC(COC(C)=O)Oc1cccc2c1CCN2C(=O)CBr</smiles>

$17(77 \%)$<smiles>CC(=O)OCC(COC(C)=O)Oc1cccc2c1CCN2C(=O)CN</smiles>

$18(90 \%)$<smiles>CC(=O)OCC(COC(C)=O)Oc1ccc([N+](=O)[O-])c2c1CCN2C(=O)CN</smiles>

$19(72 \%)$

Scheme 4. Reagents: (a) $\mathrm{NaBH}_{3} \mathrm{CN}-\mathrm{AcOH}$; (b) $\mathrm{EDC}-\mathrm{BrCH}_{2} \mathrm{CO}_{2} \mathrm{H}-\mathrm{MeCN}$; (c) $\mathrm{NaN}_{3}-\mathrm{DMF}$; (d) $\mathrm{Cu}\left(\mathrm{NO}_{3}\right)_{2}-\mathrm{Ac}_{2} \mathrm{O}-\mathrm{CH}_{2} \mathrm{Cl}_{2}$

To avoid the problem of amide hydrolysis, we instead carried out the hydrolysis step before nitration, since the amide bond in the non-nitrated indoline was expected to be much more stable. The diacetate $\mathbf{1 8}$ was readily hydrolysed to the diol $\mathbf{2 0}$ (Scheme 5) and we intended to introduce the two phosphate groups (in protected form) at this stage. Phosphorylation of a related diol in the caged GABA synthesis using phosphoramidite chemistry had been problematic because of low solubility of the diol in THF. A change to dichloromethane solvent with pyridinium trifluoroacetate (PyTFA) as the phosphitylation catalyst ${ }^{15}$ followed by oxidation with MCPBA gave the bis(di-tert-butyl phosphate) $\mathbf{2 1}$ in excellent yield. Nitration of the protected bis- 
phosphate 21 was complicated by the presence of the acid-sensitive tert-butyl esters, which underwent partial deprotection under any of the conditions tried. After numerous trial reactions, it was found that the nitration of diphosphate $\mathbf{2 1}$ was best achieved with a mixture of acetic anhydride, sodium nitrate and a four-fold excess of trichloroacetic acid (relative to the amount of $\mathrm{NaNO}_{3}$ ). As noted above, partial deprotection of the phosphate groups had taken place, indicated by the fact that the compound had become water-soluble and behaved as an anion on analytical anionexchange HPLC (see Experimental section). Rather than characterise the partially deprotected product, although it appeared to be principally a single species, we felt it was more convenient to remove the remaining tert-butyl groups but found that prior removal of excess nitrate salt from the reaction mixture was required before treatment with TFA. Without such removal, treatment of the freeze-dried reaction mixture with TFA resulted in an intractable dark mixture, and efforts to quench the excess nitrate by addition of reactive electrophiles prior to work up were also ineffective. Thus the crude water-soluble reaction mixture was subjected to preparative reverse-phase HPLC and the isolated nitroindoline product, after lyophilisation, was successfully deprotected with TFA to give 22 in $55 \%$ yield.<smiles>CCCCOC(COP(=O)(O)OCCCC)Oc1ccc([N+](=O)[O-])c2c1CCN2C(=O)CN</smiles>

Scheme 5. Reagents: (a) $\mathrm{NaOH}-$ aq. $\mathrm{MeOH}$; (b) $\mathrm{Et}_{2} \mathrm{NP}\left(\mathrm{OBu}^{t}\right)_{2}-\mathrm{PyTFA}-\mathrm{CH}_{2} \mathrm{Cl}_{2}$; (c) $\mathrm{MCPBA}$; (d) $\mathrm{NaNO}_{3}-\mathrm{Ac}_{2} \mathrm{O}-\mathrm{CCl}_{3} \mathrm{CO}_{2} \mathrm{H}-\mathrm{MeCN}$; (e) TFA; (f) TCEP-aq. DMF 
With 22 available, completion of the synthesis required only reduction of the azide group, but Staudinger reaction using either triphenylphosphine or tri- $n$-butylphosphine in aqueous DMF failed to yield pure $\mathbf{8}$ even after prolonged mild acidic treatment of the reaction mixture. It was evident from HPLC data (not shown) that an iminophosphorane was formed, as in the case of the related caged-GABA synthesis, ${ }^{10}$ but it was much more resistant to hydrolysis. This was particularly surprising since reduction of $\mathbf{1 4}$ under the same conditions had given the amine $\mathbf{1 5}$ directly upon mild acidic work-up (see above), implying ready hydrolysis of the iminophosphorane in that case. However, reduction of the azide 22 was successfully accomplished using the water-soluble tris(2-carboxyethyl)phosphine hydrochloride (TCEP) to give $\mathbf{8}$ in $47 \%$ yield after purification by anion-exchange chromatography, precipitation as its barium salt and reconversion to the sodium salt.

The photochemistry of both $\mathbf{8}$ and its model analogue $\mathbf{1 5}$ was similar to that of other $\mathrm{N}$-acyl-7-nitroindolines. Continuous irradiation of separate solutions of $\mathbf{8}$ and $\mathbf{1 5}$, monitored by UV-vis spectroscopy, as described previously, ${ }^{2,3 a, 10}$ showed progressive decrease of each starting compound and accumulation of the nitrosoindole chromophore. Clear isosbestic points were formed as photolysis progressed indicating a clean conversion (see Supplementary data). Photolysis of $\mathbf{8}$ was also monitored by HPLC and released glycine was measured by amino acid analysis, as described for related compounds.,3a Glycine recovery was in the range $68-69 \%$. This was significantly below the essentially stoichiometric release reported for other 7nitroindoline-caged amino acids and appears inconsistent with the clean spectroscopic 
data for the progressive photolysis but extensive investigations (data not shown) have not resolved this matter.

\section{Neurophysiological recordings upon glycine release by near-UV laser photolysis}

Glycine is a major inhibitory fast neurotransmitter in the mammalian spinal cord. To test the photorelease of glycine from DPNI-glycine $\mathbf{8}$ and the effects of $\mathbf{8}$ itself upon neuronal preparations, experiments were done with laser photolysis in spinal cord slices prepared from neonatal rats. Whole cell patch clamp recordings were made under conditions of high intracellular chloride ion concentration, generating inward membrane current in response to activation of glycine receptors by glycine photoreleased from 8. The morphology and identity of recorded neurons were obtained by epifluorescence imaging of the fluorophore Alexa 488 included in the intracellular solution in the whole cell-recording pipette. Photolysis was with laser pulses at $405 \mathrm{~nm}$ usually of $0.2 \mathrm{~ms}$ duration as described previously. ${ }^{11 \mathrm{a}}$ The laser spot diameter was $1 \mu \mathrm{m}$ in the focal plane and could be directed to the soma or neurites of recorded neurons with sub-micron accuracy. The experimental methods are described in Supplementary data.

Responses recorded in a motoneuron to concentrations of glycine released at different laser intensities in $0.2 \mathrm{~ms}$ pulses from DPNI-glycine 8, present at $2 \mathrm{mM}$, are shown in Figure 1A. The amplitude of the response increases with laser intensity (0.4 to 8.1 mW) up to the point of saturation, as shown in the bar chart of Figure 1D. The 20$80 \%$ rise-times increased from $1.2 \pm 0.2$ to $2.8 \pm 0.5 \mathrm{~ms}$ with increasing intensity of the pulse. For comparison, the rise time of spontaneous post-synaptic currents (shown in Figure 1B) is in the $0.3-1.1 \mathrm{~ms}$ range, over a population of 12 cells. As the laser 
intensity was increased, also the decay time constant increased, from $8.1 \pm 0.4$ to 28.0 $\pm 6.1 \mathrm{~ms}$, compared with corresponding values for spontaneous currents of between 4.2 and $9.1 \mathrm{~ms}$. The slower rise and fall of the responses to photolytically released glycine is apparent in the normalised and superimposed traces of Figure 1C. For comparison, an average of spontaneous post-synaptic currents is also shown. The slower kinetics may be attributed to the larger volume into which glycine is released by laser spot photolysis compared with the volume of synaptic release.

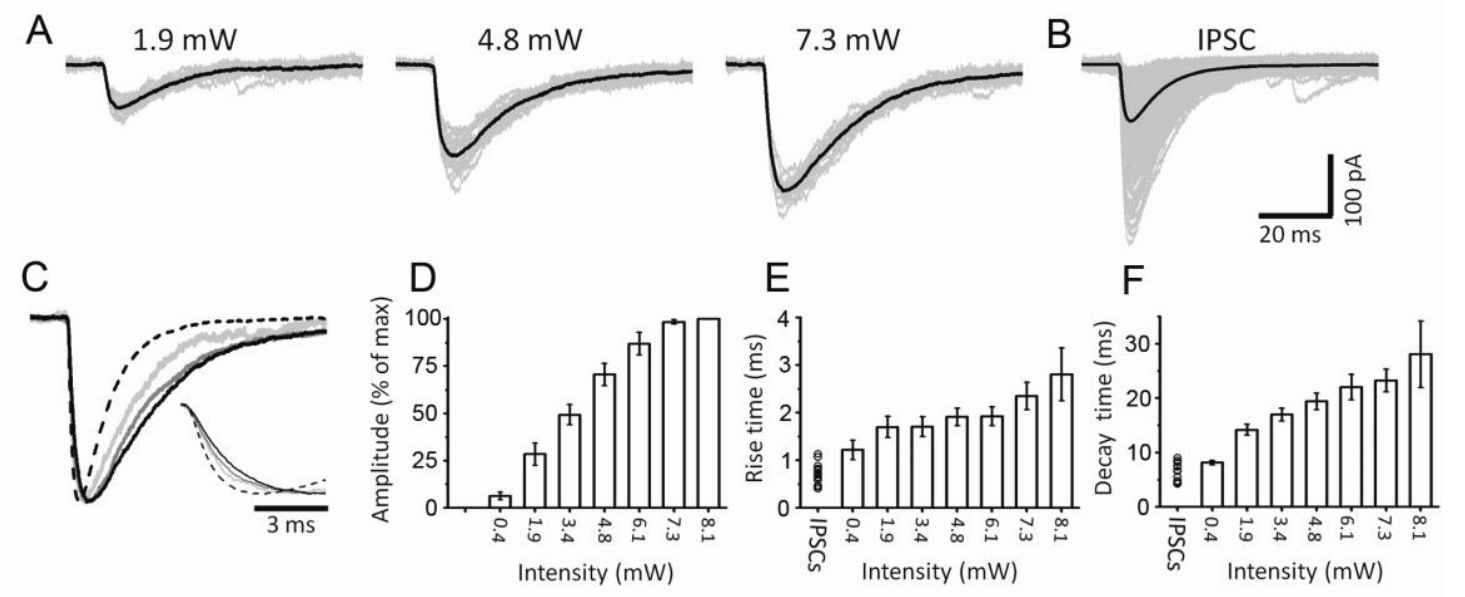

Figure 1 Responses in spinal motorneurons under whole cell voltage clamp to laserevoked photolysis of extracellular $2 \mathrm{mM}$ DPNI-glycine 8 in a $1 \mu \mathrm{m}$ focal spot. Negative deflections show inward membrane current due to $\mathrm{Cl}^{-}$ion flux through receptor ion channels activated by glycine binding. (A) Increasing intensity of the laser pulse (duration $0.2 \mathrm{~ms}$ ) generates progressively larger amplitudes of response. Grey traces are superimposed individual events; black traces are the mean at each intensity. Laser power in $\mathrm{mW}$ is given at the objective, with $2 \mathrm{mM}$ of $\mathbf{8}$ present in the bath $50 \%$ of the light is absorbed by inner filtering. (B) For comparison spontaneous glycine synaptic responses and their mean are shown on the same scale. (C) The time course of normalised responses to low (light grey), medium and high intensity (black) pulses are compared with synaptic responses (dashed line) on the same time-scale. The inset shows a time scale expansion of the rise times of the averaged response (continuous lines) and of spontaneous events (dashed line). (D, E, F) Summary bar charts of data from 12 neurons of the peak amplitude (D), the $20-80 \%$ rise-time (E) and the exponential time-constant of response decline $(F)$. In panels $(E)$ and $(F)$ the left column is data for spontaneous IPSCs due to synaptic glycine release in the same neurons, other columns show responses to glycine released by different laser intensities. 
Direct interference between uncaged DPNI-glycine $\mathbf{8}$ and glycine receptors was tested by measuring the amplitude of spontaneous synaptic currents in control and in the presence of $3 \mathrm{mM}$ DPNI-glycine. The mean event amplitudes as well as their rise times did not change in the two conditions (see Supplementary data Figure S2 and text). However, following repetitive uncaging on the same spot, a rundown of the light evoked current was consistently observed (Figure S2 and text). The origin of this rundown will require further investigations, but it could be associated with the observed incomplete stoichiometry obtained on photolysis of DPNI-glycine.

\section{Conclusions}

The synthesis of $\mathbf{8}$ was successfully accomplished but, despite its similarity to the previously described caged GABA 7, significant modification of the previously established synthetic route was required. The unexpected reactivity of the densely functionalised intermediate compounds was surmounted by employing more effective reagents and appropriate reaction conditions. The controlled nitration of indolines in synthesis of these caged compounds remains subject to a need for individual optimisation, while the improved phosphorylation method could usefully be applied to a better synthesis of the caged GABA 7.

Release of glycine on spinal cord neurons by localised laser photolysis of $\mathbf{8}$ showed fast activation of glycinergic currents with time-course in the ms range. Although slower than glycine mediated synaptic currents recorded in the same neurons, the kinetics of activation by photoreleased glycine are nonetheless fast enough to be useful in experiments to determine the distribution of glycine sensitivity in neuronal compartments and to yield kinetic data of glycine receptor function at synaptic sites in situ. A further appealing feature of $\mathbf{8}$ is that, contrary to the block of GABA $(\gamma-$ 
aminobutyric acid) responses seen with the caged GABA analogue DPNI-GABA 7, DPNI-gly does not interact with the glycine receptors. The origin of the run-down of responses seen with multiple pulses of DPNI-glycine photolysis applied consecutively to the same sites was not elucidated in the experiments described here. The present synthesis has provided enough material for further pharmacological characterisation and these studies will be reported elsewhere in due course.

\section{Experimental}

\subsection{General}

${ }^{1} \mathrm{H}$ NMR spectra were determined on Varian Inova $600 \mathrm{MHz}$ or Varian Inova 800 $\mathrm{MHz}$ spectrometers in $\mathrm{CDCl}_{3}$ solution with TMS as internal reference, unless otherwise specified. Elemental analyses were carried out by MEDAC Ltd., Surrey, UK. Electrospray mass spectra were recorded at the School of Pharmacy, University of London. Merck 9385 silica gel was used for flash chromatography. Analytical HPLC was performed on a $250 \times 4$ mm Merck Lichrospher RP8 column or a $125 \times 4$ mm Whatman Partisphere SAX column. Flow rates were $1.5 \mathrm{~mL} \mathrm{~min}^{-1}$ with either column. Preparative HPLC was carried out on a $2 \times 30 \mathrm{~cm}$ column (Waters $\mathrm{C}_{18}$ packing, Cat. No. 20594) at $2 \mathrm{~mL} \mathrm{~min}{ }^{-1}$ flow rate. Details of mobile phases are given at relevant points in the text. Preparative anion-exchange chromatography used a column of DEAE-cellulose $(2 \times 20 \mathrm{~cm})$. Detection for all analytical and preparative chromatography was at $254 \mathrm{~nm}$. Organic solvents were dried over anhydrous $\mathrm{Na}_{2} \mathrm{SO}_{4}$ and evaporated under reduced pressure. Hexanes (bp 40-60 ${ }^{\circ} \mathrm{C}$ ) were redistilled before use. Photolysis experiments were performed in a Rayonet RPR-100 photochemical reactor fitted with $16 \times 350 \mathrm{~nm}$ lamps. 


\subsection{1-(2-Bromoacetyl)-4-(1,3-diacetoxypropan-2-yloxy)indoline (17)}

A solution of 4-(1,3-diacetoxypropan-2-yloxy)indoline (2.93 g, $10 \mathrm{mmol}$; prepared from 16 as previously described $\left.{ }^{10}\right)$ in $\operatorname{dry} \mathrm{MeCN}(70 \mathrm{~mL})$ was treated with 2bromoacetic acid (2.08 g, $15 \mathrm{mmol}$ ), followed by 1-(3-dimethylaminopropyl)-3ethylcarbodiimide hydrochloride $(2.68 \mathrm{~g}, 14 \mathrm{mmol})$ and the mixture was stirred at $\mathrm{rt}$ under nitrogen overnight. The solvent was evaporated and the residue was taken up in EtOAc $(80 \mathrm{~mL})$, washed with dilute aq. $\mathrm{HCl}$, saturated aq. $\mathrm{NaHCO}_{3}$ and brine, dried and evaporated to pale crystals. Recrystallisation (EtOAc-hexanes) followed by flash chromatography [EtOAc-hexanes (2:3)] of the mother liquor gave 17 (3.17 g, 77\%) as white crystals, mp $77-79{ }^{\circ} \mathrm{C}\left(\right.$ EtOAc-hexanes); ${ }^{1} \mathrm{H}$ NMR $(600 \mathrm{MHz}) \delta 7.87(\mathrm{~d}, J=$ $8.2 \mathrm{~Hz}, 1 \mathrm{H}), 7.19(\mathrm{t}, J=8.2 \mathrm{~Hz}, 1 \mathrm{H}), 6.73(\mathrm{~d}, J=8.2 \mathrm{~Hz}, 1 \mathrm{H}), 4.71$ (quintet, $J=5.2$ $\mathrm{Hz}, 1 \mathrm{H}), 4.34(\mathrm{dd}, J=5.7,11.9 \mathrm{~Hz}, 2 \mathrm{H}), 4.29(\mathrm{dd}, J=4.9,11.9 \mathrm{~Hz}, 2 \mathrm{H}), 4.21$ and $4.18(2 \times \mathrm{t}, J=8.5 \mathrm{~Hz}, 2 \mathrm{H}$, rotamers), $4.16(\mathrm{~s}, 2 \mathrm{H}), 3.16(\mathrm{t}, J=8.5 \mathrm{~Hz}, 2 \mathrm{H}), 2.07(\mathrm{~s}$, 6H). Anal. Calcd for $\mathrm{C}_{17} \mathrm{H}_{20} \mathrm{NO}_{6} \mathrm{Br}$ : C, 49.29; H, 4.87; N, 3.38. Found: C, 49.53; H, $4.67 ; \mathrm{N}, 3.63$.

\subsection{1-(2-Azidoacetyl)-4-(1,3-diacetoxypropan-2-yloxy)indoline (18)}

$\mathrm{NaN}_{3}(0.97 \mathrm{~g}, 15 \mathrm{mmol})$ was added to a solution of $17(2.07 \mathrm{~g}, 5 \mathrm{mmol})$ in dry DMF (40 $\mathrm{mL}$ ) and the mixture was stirred at rt overnight. The solvent was removed under reduced pressure and the residue was diluted with EtOAc $(70 \mathrm{~mL})$, washed with water and brine, dried and evaporated to give 18 as white crystals (1.69 g, 90\%), mp 64-65 ${ }^{\circ} \mathrm{C}\left(\mathrm{Et}_{2} \mathrm{O}-\right.$-hexanes$) ;{ }^{1} \mathrm{H}$ NMR $(600 \mathrm{MHz}) \delta 7.89(\mathrm{~d}, J=8.1 \mathrm{~Hz}, 1 \mathrm{H}), 7.19(\mathrm{t}, J=8.1$ $\mathrm{Hz}, 1 \mathrm{H}), 6.72(\mathrm{~d}, J=8.1 \mathrm{~Hz}, 1 \mathrm{H}), 4.71$ (quintet, $J=5.2 \mathrm{~Hz}, 1 \mathrm{H}), 4.34(\mathrm{dd}, J=5.8$, $11.9 \mathrm{~Hz}, 2 \mathrm{H}), 4.29(\mathrm{dd}, J=4.7,11.9 \mathrm{~Hz}, 2 \mathrm{H}), 4.00(\mathrm{t}, J=8.2 \mathrm{~Hz}, 2 \mathrm{H}), 3.97(\mathrm{~s}, 2 \mathrm{H})$, $3.14(\mathrm{t}, J=8.2 \mathrm{~Hz}, 2 \mathrm{H}), 2.06(\mathrm{~s}, 6 \mathrm{H})$. Anal. Calcd for $\mathrm{C}_{17} \mathrm{H}_{20} \mathrm{~N}_{4} \mathrm{O}_{6}: \mathrm{C}, 54.25 ; \mathrm{H}, 5.36$; 
N, 14.89. Found: C, 54.29; H, 5.52; N, 14.68.

\subsection{1-(2-Azidoacetyl)-4-(1,3-diacetoxypropan-2-yloxy)-7-nitroindoline (19)}

To a solution of $\mathbf{1 8}(489 \mathrm{mg}, 1.35 \mathrm{mmol})$ in a mixture of $\mathrm{CH}_{2} \mathrm{Cl}_{2}(13.5 \mathrm{~mL})$ and acetic anhydride $(27 \mathrm{~mL})$ was added copper nitrate hemipentahydrate $(365 \mathrm{mg}, 1.75 \mathrm{mmol})$ and the mixture was stirred at $\mathrm{rt}$ overnight. The solution was concentrated and the residue was re-evaporated from toluene, diluted with EtOAc $(50 \mathrm{~mL})$ and washed with saturated aqueous $\mathrm{NaHCO}_{3}$ and brine, dried and evaporated to brown viscous oil. Flash chromatography [EtOAc-hexanes (1:1)], followed by trituration with ether, gave 19 (407 mg, 72\%) as yellow crystals, mp 90-91 ${ }^{\circ} \mathrm{C}$ (EtOAc-hexanes); ${ }^{1} \mathrm{H}$ NMR $(800 \mathrm{MHz}) \delta 7.80(\mathrm{~d}, J=9.0 \mathrm{~Hz}, 1 \mathrm{H}), 6.84(\mathrm{~d}, J=9.0 \mathrm{~Hz}, 1 \mathrm{H}), 4.82$ (quintet, $J=5.3$ $\mathrm{Hz}, 1 \mathrm{H}), 4.36(\mathrm{dd}, J=5.9,11.9 \mathrm{~Hz}, 2 \mathrm{H}), 4.31(\mathrm{dd}, J=4.7,11.9 \mathrm{~Hz}, 2 \mathrm{H}), 4.22(\mathrm{t}, J=$ $8.1 \mathrm{~Hz}, 2 \mathrm{H}), 4.04(\mathrm{~s}, 2 \mathrm{H}), 3.12(\mathrm{t}, J=8.1 \mathrm{~Hz}, 2 \mathrm{H}), 2.07(\mathrm{~s}, 6 \mathrm{H})$. Anal. Calcd for $\mathrm{C}_{17} \mathrm{H}_{19} \mathrm{~N}_{5} \mathrm{O}_{8}: \mathrm{C}, 48.46 ; \mathrm{H}, 4.54 ; \mathrm{N}, 16.61$. Found: $\mathrm{C}, 48.12 ; \mathrm{H}, 4.47 ; \mathrm{N}, 16.37$.

\subsection{1-(2-Azidoacetyl)-4-(1,3-dihydroxypropan-2-yloxy)indoline (20)}

A solution of $18(1.51 \mathrm{~g}, 4 \mathrm{mmol})$ in $\mathrm{MeOH}(80 \mathrm{~mL})$, water $(8 \mathrm{~mL})$ and $1 \mathrm{M}$ aq. $\mathrm{NaOH}(9.6 \mathrm{~mL}, 9.6 \mathrm{mmol})$ was stirred at $\mathrm{rt}$ for $2 \mathrm{~min}$, quenched with $1 \mathrm{M}$ aq. citric acid $(19.2 \mathrm{~mL})$ and concentrated to $\sim 40 \mathrm{~mL}$. The solution was diluted with water (20 $\mathrm{mL})$, extracted with EtOAc $(3 \times 40 \mathrm{~mL})$ and the combined organic extract was washed with saturated aq. $\mathrm{NaHCO}_{3}$ and brine, dried and evaporated to give 20 (1.00 $\mathrm{g}, 85 \%)$ as white crystals, mp $110-112{ }^{\circ} \mathrm{C}$ (EtOAc-hexanes); ${ }^{1} \mathrm{H}$ NMR (800 MHz; DMSO- $\left.d_{6}\right) \delta 7.66(\mathrm{~d}, J=8.1 \mathrm{~Hz}, 1 \mathrm{H}), 7.13(\mathrm{t}, J=8.1 \mathrm{~Hz}, 1 \mathrm{H}), 6.78(\mathrm{~d}, J=8.1 \mathrm{~Hz}$, $1 \mathrm{H}), 4.77(\mathrm{t}, J=5.5 \mathrm{~Hz}, 2 \mathrm{H}), 4.26$ (quintet, $J=5.5 \mathrm{~Hz}, 1 \mathrm{H}), 4.22(\mathrm{~s}, 2 \mathrm{H}), 4.00(\mathrm{t}, J=$ 8.4 Hz, 2H), 3.58-3.61 (m, 2H), 3.33-3.56 (m, 2H), $3.04(\mathrm{t}, J=8.4 \mathrm{~Hz}, 2 \mathrm{H})$. Anal. 
Calcd for $\mathrm{C}_{13} \mathrm{H}_{16} \mathrm{~N}_{4} \mathrm{O}_{4}$ : C, 53.42; H, 5.52; N, 19.16. Found: C, 53.69; H, 5.61; N, 18.80.

\subsection{1-(2-Azidoacetyl)-4-[1,3-bis(di-tert-butoxyphosphoryloxy)propan-2-} yloxy]indoline (21)

A solution of $20(0.58 \mathrm{~g}, 2 \mathrm{mmol})$ in dry $\mathrm{CH}_{2} \mathrm{Cl}_{2}(60 \mathrm{~mL})$ was treated under nitrogen with pyridinium trifluoroacetate $(1.16 \mathrm{~g}, 6 \mathrm{mmol})$ and di-tert-butyl $N, N$ diethylphosphoramidite (93\% purity; $1.61 \mathrm{~g}, 6 \mathrm{mmol}$ ) and the mixture was stirred under nitrogen at $\mathrm{rt}$ for $20 \mathrm{~min}$. The solution was cooled to $0{ }^{\circ} \mathrm{C}$ and treated dropwise with a solution of $m$-chloroperbenzoic acid (77\% peracid; $2.69 \mathrm{~g}, 12 \mathrm{mmol})$ in $\mathrm{CH}_{2} \mathrm{Cl}_{2}$ (60 mL). The solution was stirred at $4{ }^{\circ} \mathrm{C}$ for $45 \mathrm{~min}$, diluted with $\mathrm{CH}_{2} \mathrm{Cl}_{2}$ and washed successively with $10 \%$ aq. $\mathrm{Na}_{2} \mathrm{~S}_{2} \mathrm{O}_{5}$, saturated aq. $\mathrm{NaHCO}_{3}$ and brine, dried and evaporated. Flash chromatography (EtOAc) gave 21 (1.19 g, 88\%) as white crystals, mp 78-80 ${ }^{\circ} \mathrm{C}\left(\mathrm{Et}_{2} \mathrm{O}-\right.$ hexanes$) ;{ }^{1} \mathrm{H}$ NMR $(600 \mathrm{MHz}) \delta 7.87(\mathrm{~d}, J=8.2 \mathrm{~Hz}, 1 \mathrm{H}), 7.18(\mathrm{t}$, $J=8.2 \mathrm{~Hz}, 1 \mathrm{H}), 6.75(\mathrm{~d}, J=8.2 \mathrm{~Hz}, 1 \mathrm{H}), 4.70$ (quintet, $J=4.9 \mathrm{~Hz}, 1 \mathrm{H}), 4.18(\mathrm{~d}, J=$ $5.2 \mathrm{~Hz}, 2 \mathrm{H}), 4.17(\mathrm{~d}, J=5.2 \mathrm{~Hz}, 2 \mathrm{H}), 3.98(\mathrm{t}, J=8.4 \mathrm{~Hz}, 2 \mathrm{H}), 3.97(\mathrm{~s}, 2 \mathrm{H}), 3.18(\mathrm{t}, J$ $=8.4 \mathrm{~Hz}, 2 \mathrm{H}), 1.47(\mathrm{~s}, 18 \mathrm{H}), 1.45(\mathrm{~s}, 18 \mathrm{H})$. Anal. Calcd for $\mathrm{C}_{29} \mathrm{H}_{50} \mathrm{~N}_{4} \mathrm{O}_{10} \mathrm{P}_{2}: \mathrm{C}, 51.47$; H, 7.45; N, 8.28. Found: C, 51.87; H, 7.591; N, 8.18.

\subsection{1-(2-Azidoacetyl)-4-[1,3-bis(dihydroxyphosphoryloxy)propan-2-yloxy]-7-} nitroindoline (22)

To a solution of 21 (237 mg, $0.35 \mathrm{mmol})$ in dry $\mathrm{MeCN}(3.5 \mathrm{~mL})$ was added acetic anhydride (357 mg, $3.5 \mathrm{mmol})$, sodium nitrate $(59.5 \mathrm{mg}, 0.7 \mathrm{mmol})$ and trichloroacetic acid (457 mg, $2.8 \mathrm{mmol})$ and the mixture was stirred under nitrogen at rt for $24 \mathrm{~h}$. TLC [MeOH-EtOAc (1:19)] confirmed that all starting material was 
consumed. The reaction mixture was diluted with $200 \mathrm{mM} \mathrm{NaOAc}$, pH 6.0 (70 mL), the $\mathrm{pH}$ was raised from 4.8 to 5.5 with $1 \mathrm{M}$ aq. $\mathrm{NaOH}$ and the solution was washed with $\mathrm{Et}_{2} \mathrm{O}(3 \times 50 \mathrm{~mL})$. Analysis of the aqueous phase by reverse phase HPLC [mobile phase $25 \mathrm{mM}$ Na phosphate, $\mathrm{pH} 6.0-\mathrm{MeCN}(25: 1), t_{\mathrm{R}} 5.8 \mathrm{~min}$ ], and by anionexchange HPLC [mobile phase $100 \mathrm{mM}$ Na phosphate, $\mathrm{pH}$ 6.0-MeCN (5:1), $t_{\mathrm{R}} 5.2$ min], confirmed that all starting material was nitrated but partial deprotection of phosphate esters took place. The solution was loaded onto the preparative HPLC column, which was pre-equilibrated with $200 \mathrm{mM} \mathrm{NaOAc}, \mathrm{pH} 6.0$, and subsequently eluted with the same buffer for further $1.5 \mathrm{~h}$. The column was then washed with water and the compound began to elute after about $1 \mathrm{~h}$, when the conductivity of the eluate had lowered to that of water. The fractions containing the compound were combined, concentrated to about $25 \mathrm{~mL}$ and lyophilised. The pale yellow residue was dissolved in TFA $(15 \mathrm{~mL})$ and stirred at $\mathrm{rt}$ for $1 \mathrm{~h}$. The solvent was evaporated, the residue was dissolved in $25 \mathrm{mM}$ triethylammonium phosphate, $\mathrm{pH} 6.0(75 \mathrm{~mL})$ and the $\mathrm{pH}$ was raised from 2.6 to 6.0 with $1 \mathrm{M}$ aq. $\mathrm{NaOH}$. HPLC analysis as above confirmed full deprotection of the phosphate esters. The solution was loaded onto the preparative HPLC column, which was pre-equilibrated with $25 \mathrm{mM}$ triethylammonium phosphate, $\mathrm{pH}$ 6.0, and subsequently eluted with the same buffer for further $1 \mathrm{~h}$. The column was then washed with water and the compound began to elute after about $50 \mathrm{~min}$, when the conductivity of the eluate had lowered to that of water. Fractions containing the compound were analysed by reverse phase HPLC [mobile phase $100 \mathrm{mM} \mathrm{Na}$ phosphate, $\mathrm{pH}$ 6.0-MeCN $(25: 1), t_{\mathrm{R}} 3.6 \mathrm{~min}$ ], and by anion-exchange HPLC [mobile phase $100 \mathrm{mM}$ Na phosphate, $\mathrm{pH}$ 6.0-MeCN (5:1), $\left.t_{\mathrm{R}} 5.8 \mathrm{~min}\right]$, combined and concentrated. The residue was taken up in water $(35.5 \mathrm{~mL})$, passed through a $0.2 \mu \mathrm{m}$ membrane and quantified by UV-vis spectroscopy to give pure $22(5.47 \mathrm{mM}, 194$ 
$\mu \mathrm{mol}, 55 \%)$. An aliquot $(0.6 \mathrm{ml})$ was exchanged to the $\mathrm{Na}^{+}$salt (Dowex $50, \mathrm{Na}^{+}$ form); ${ }^{1} \mathrm{H}$ NMR (600 MHz, $\mathrm{D}_{2} \mathrm{O}$, acetone ref.) $\delta 7.85(\mathrm{~d}, J=9.0 \mathrm{~Hz}, 1 \mathrm{H}), 7.13(\mathrm{~d}, J=$ $9.0 \mathrm{~Hz}, 1 \mathrm{H}), 4.92$ (quintet, $J=4.7 \mathrm{~Hz}, 1 \mathrm{H}), 4.37(\mathrm{~s}, 2 \mathrm{H}), 4.25$ (t, $J=7.8 \mathrm{~Hz}, 2 \mathrm{H}), 4.09$ - $4.17(\mathrm{~m}, 4 \mathrm{H}), 3.23(\mathrm{t}, J=7.9 \mathrm{~Hz}, 2 \mathrm{H})$. LRMS (ESI): calcd for $\left(\mathrm{C}_{13} \mathrm{H}_{13} \mathrm{~N}_{5} \mathrm{O}_{12} \mathrm{P}_{2}+\right.$ $3 \mathrm{H})^{-}, 496.0$, found: 495.9. The remainder of the solution was lyophilised to a pale yellow solid and used in the next step.

\subsection{1-(2-Aminoacetyl)-4-[1,3-bis(dihydroxyphosphoryloxy)propan-2-yloxy]-7- nitroindoline (8)}

A solution of $22(191 \mu \mathrm{mol})$ in water $(3 \mathrm{~mL})$ was diluted with DMF $(27 \mathrm{~mL})$ and treated with tris(2-carboxyethyl)phosphine hydrochloride (TCEP) (383 mg, 1.34 mmol) and the mixture was stirred at rt under nitrogen for $28 \mathrm{~h}$. The solution was concentrated under reduced pressure and the residue was diluted with water $(50 \mathrm{~mL})$ and washed with EtOAc $(3 \times 40 \mathrm{~mL})$. Analysis by reverse phase HPLC [mobile phase $25 \mathrm{mM} \mathrm{Na}$ phosphate, $\mathrm{pH}$ 6.0-MeCN $\left.(25: 1), t_{\mathrm{R}} 1.8 \mathrm{~min}\right]$, and by anion-exchange HPLC [mobile phase $100 \mathrm{mM}$ Na phosphate, $\mathrm{pH}$ 6-MeCN (5:1), $1.5 \mathrm{~mL} / \mathrm{min}, t_{\mathrm{R}} 5.2$ min confirmed complete reduction of the azide. The solution was then adjusted to $\mathrm{pH}$ 6.0 with $1 \mathrm{M}$ aq. $\mathrm{NaOH}$ and quantified by UV-vis spectroscopy $(51 \mathrm{ml}, 3.7 \mathrm{mM}, 189$ $\mu \mathrm{mol})$. The solution was diluted with water $(250 \mathrm{~mL})$ to conductivity $5.3 \mathrm{mS} \mathrm{cm}^{-1}$ and subjected to anion-exchange chromatography using a linear gradient formed from 10 and $500 \mathrm{mM}$ NaOAc, pH 6.0 (each $1000 \mathrm{~mL}$ ). Fractions containing the product, which eluted at $\sim 300 \mathrm{mM} \mathrm{NaOAc}$, were analysed as above, combined (144 mL) and quantified by UV spectroscopy $(0.678 \mathrm{mM}, 98 \mu \mathrm{mol})$. The solution was concentrated to about $4 \mathrm{~mL}$, diluted with water to $8 \mathrm{~mL}$, treated with $2 \mathrm{M} \mathrm{Ba}(\mathrm{OAc})_{2}(2 \mathrm{~mL})$ and EtOH (4 mL) and allowed to stand at $4{ }^{\circ} \mathrm{C}$ overnight. The mixture was centrifuged 
and the supernatant was analysed by UV-vis spectroscopy (9\% of original concentration, i.e. $91 \%$ precipitation). The precipitate was washed with water-EtOH $(1: 1)(5 \times 15 \mathrm{~mL})$ by resuspension and subsequent centrifugation after each wash cycle. The final precipitate was dissolved in water $(15 \mathrm{~mL})$ and mixed with Dowex 50 $\left(\mathrm{Na}^{+}\right.$form; $\left.4 \mathrm{~g}\right)$ for $2 \mathrm{~h}$. The resin was filtered off, washed with water $(20 \mathrm{~mL})$ and the combined filtrates were adjusted from $\mathrm{pH} 8.4$ to 6.8 with $1 \mathrm{M}$ aq. $\mathrm{HCl}$. The filtrate was passed through a $0.2 \mu \mathrm{m}$ membrane filter, lyophilised and the residue was dissolved in water ( $4 \mathrm{~mL}$ ) and quantified by UV-vis spectroscopy to give $\mathbf{8}$ ( $22.3 \mathrm{mM}$, $89 \mu \mathrm{mol}, 47 \%)$ as the $\mathrm{Na}^{+}$salt; [containing a small amount of tris(2carboxyethyl)phosphine oxide in approximately (4:1) ratio], ${ }^{1} \mathrm{H}$ NMR (500 MHz, $\mathrm{D}_{2} \mathrm{O}$, acetone ref.) $\delta 8.00$ and $7.86(2 \times \mathrm{d}, J=9.2 \mathrm{~Hz}, 1 \mathrm{H}$, rotamers $), 7.90$ and $7.20(2$ $\times \mathrm{d}, J=9.2 \mathrm{~Hz}, 1 \mathrm{H}$, rotamers $), 4.89$ and $4.55(2 \times$ quintet, $J=5.0 \mathrm{~Hz}, 1 \mathrm{H}$, rotamers $)$, 4.27 and $4.21(2 \times \mathrm{t}, J=7.9 \mathrm{~Hz}, 2 \mathrm{H}$, rotamers $), 4.14(\mathrm{~s}, 2 \mathrm{H}), 4.00-4.07(\mathrm{~m}, 4 \mathrm{H}), 3.47$ and $3.27\left(2 \times \mathrm{t}, J=7.9 \mathrm{~Hz}, 2 \mathrm{H}\right.$, rotamers). LRMS (ESI): calcd for $\left(\mathrm{C}_{13} \mathrm{H}_{16} \mathrm{~N}_{3} \mathrm{O}_{12} \mathrm{P}_{2}+\right.$ $2 \mathrm{H})^{-}, 470.0$, found: 470.0. Complete separation from tris(carboxyethyl)phosphine oxide was not achieved in the purification, as shown by signals in the ${ }^{1} \mathrm{H}$ NMR spectrum at $\delta \quad 2.38-2.43 \quad\left[\mathrm{~m}, \quad \mathrm{P}(\mathrm{O})\left(\mathrm{CH}_{2} \mathrm{CH}_{2} \mathrm{CO}_{2}\right)_{3}\right], \quad 2.09-2.14 \quad[\mathrm{~m}$, $\left.\mathrm{P}(\mathrm{O})\left(\mathrm{CH}_{2} \mathrm{CH}_{2} \mathrm{CO}_{2}\right)_{3}\right]$, with intensities corresponding to $\sim 20 \mathrm{~mol} \%$ of the concentration of $\mathbf{8}$.

\subsection{Quantitative photolysis and product analysis for (8)}

Separate solutions of $8(0.47 \mathrm{mM}$ in $25 \mathrm{mM}$ Na phosphate, $\mathrm{pH} 7.0$ containing $5 \mathrm{mM}$ dithiothreitol) were irradiated for varying times ( 20 or $25 \mathrm{~s}$ ) in $1 \mathrm{~mm}$ path length cells (Rayonet Photochemical Reactor). The solutions were analysed by anion-exchange HPLC (mobile phase as in Section 4.8) and the extent of photolysis of each solution 
was determined by comparison of peak heights with those of non-irradiated controls. Aliquots of the photolysed solutions were also subjected to quantitative amino acid analysis. Measured glycine concentrations were $68-69 \%$ of the expected values from the extent of photolysis and were not affected by the concentration of dithiothreitol. The stock solution (20.9 $\mathrm{mM}$ ) was also subjected to quantitative amino acid analysis and the measured free glycine contamination was $0.35 \%$.

In a further experiments, separate solutions of 8 and $15(0.51 \mathrm{mM})$ in $25 \mathrm{mM} \mathrm{Na}$ phosphate, $\mathrm{pH} 7.0$ were irradiated for increasing times $(0-90 \mathrm{~s})$ in a 1-mm path length cell and the extent of photolysis was monitored after each irradiation interval by UVvis spectroscopy.

\section{Acknowledgements}

We are grateful to Dr J. E. T. Corrie for useful discussions and to Dr G. Kelly for recording NMR spectra. We thank the MRC for financial support (project number U117592730) and the MRC Biomedical NMR Centre for access to facilities.

\section{Supplementary data}

Experimental details for compounds 9-15, hydrolysis of 19 and details of neurophysiological experiments of $\mathbf{8}$ together with the elucidation of some results are given in the Supplementary data.

\section{References and notes}

1 (a) Corrie, J. E. T. In Dynamic Studies in Biology: Phototriggers, Photoswitches and Caged Biomolecules, Goeldner, M.; Givens, R., Eds.; Wiley VCH: 
Weinheim, 2005; pp 1-28; (b) Adams, S. R.; Tsien.; R. Y. Annu. Rev. Physiol., 1993, 55, 755-784; (c) Kaplan, J. H. Annu. Rev. Physiol., 1990, 52, 897-914; (d) Marriott, G., Ed. Methods in Enzymology, Academic Press: New York, 1998; Vol. 291. (e) Pelliccioli, A.; Wirz, J. Photochem. Photobiol. Sci., 2002, 1, 441-458.

2. Papageorgiou, G.; Ogden, D. C.; Barth, A.; Corrie, J. E. T. J. Am. Chem. Soc. 1999, 121, 6503-6504.

3. (a) Papageorgiou, G.; Corrie, J. E. T. Tetrahedron 2000, 56, 8197-8205; (b) Papageorgiou, G.; Corrie, J. E. T. Synth. Commun. 2002, 32, 1571-1577.

4. Canepari, M.; Nelson, L.; Papageorgiou, G.; Corrie, J. E. T.; Ogden, D. J. Neurosci. Methods 2001, 112, 29-42.

5. Maier, W.; Corrie, J. E. T.; Papageorgiou, G.; Laube, B.; Grewer, C. J. Neurosci. Methods 2005, 142, 1-9.

6. Zhang, Z.; Papageorgiou, G.; Corrie, J. E. T.; Grewer, C. Biochemistry 2007, 46, $3872-3880$

7. Canepari, M.; Papageorgiou, G.; Corrie, J. E. T.; Watkins, C.; Ogden, D. J. Physiol. 2001, 533, 756-772.

8. (a) Matsuzaki, M., Ellis-Davies, G. C. R.; Nemoto, T.; Miyashita, Y.; Iino, M.; Kasai, M. Nat. Neurosci. 2001, 4, 1086-1092; (b) Smith, M. A.; Ellis-Davies, G. C. R.; Magee, J. C. J. Physiol. 2003, 548, 245-258; (c) Canepari, M.; Ogden, D. J. Neurosci. 2003, 23, 4066-4071; (d) Lowe, G. J. Neurophysiol. 2003, 90, 1737-1746; (e) Shepherd, G. M. G.; Pologruto, T. A.; Svoboda, K. Neuron 2003, 38, 277-289; (f) Canepari, M.; Auger, C.; Ogden, D. J. Neurosci. 2004, 24, 3563-3573; (g) Matsuzaki, M.; Honkura, N.; Ellis-Davies, G. C. R.; Kasai, H. Nature 2004, 429, 761-766; (h) Carter, A. G.; Sabatini, B. L. Neuron 2004, 44, 483-493; (i) Bureau, I.; Shepherd, G. M. G.; Svoboda, K. Neuron 2004, 42, 
789-801; (j) Huang, Y. H. H.; Sinha, S R.; Fedoryak, O. D.; Ellis-Davies, G. C. R.; Bergles, D. E. Biochemistry 2005, 44, 3316-3326; (k) Bloodgood, B. L.; Sabatini, B. Science, 2006, 310, 866-869; (1) Canepari, M.; Ogden, D. J Physiol., 2006, 573, 65-82.

9. Morrison, J.; Wan, P.; Corrie, J. E. T.; Papageorgiou, G. Photochem. Photobiol. Sci. 2002, 1, 960-969.

10. Papageorgiou, G.; Corrie, J. E. T. Tetrahedron 2007, 63, 9668-9676.

11. (a) Trigo, F. F.; Papageorgiou, G.; Corrie, J. E. T.; Ogden, D. J. Neurosci. Methods 2009, 181, 159-69; (b) Trigo, F. F.; Bouhours, B.; Rostaing, P.; Papageorgiou, G.; Corrie, J. E. T.; Triller, A.; Ogden, D.; Marty, A. Neuron 2010, 66, 235-247.

12. Ueno, S.; Nabekura, J.; Ishbashi, H.; Akaike, N.; Mori, M.; Shiga, M. J. Neurosci. Methods 1995, 58, 163-166.

13. Papageorgiou, G.; Ogden, D.; Corrie, J. E. T. J. Org. Chem. 2004, 69, 72287233.

14. Kawada, A.; Takeda, S.; Yamashita, K.; Abe, H.; Harayama, T. Chem. Pharm. Bull. 2002, 50, 1060-1065.

15. (a) Sangvi, S. Y.; Guo, Z.; Pfundheller, H. M.; Converso, A. Org. Process Res. Dev. 2000, 4, 175-181; (b) Zhang, Y.; Heisen, M. H.; Kostic, M.; Pagani, G. M.; Riera, T. V.; Perovic, I.; Hedstrom, L.; Snider, B. B.; Pochapsky, T. C.; Bioorg. Med. Chem. 2004, 12, 3847-3855. 


\title{
Synthesis and photolytic evaluation of a nitroindoline-caged glycine with a side chain of high negative charge for use in neuroscience
}

\author{
George Papageorgiou, ${ }^{a}$ Marco Beato ${ }^{\mathrm{b}}$ and David Ogden ${ }^{\mathrm{c}}$
}

a. MRC National Institute for Medical Research, The Ridgeway, Mill Hill, London NW7 1AA, UK

b. Department of Neuroscience, Physiology and Pharmacology, University College London, Gower Street, London WC1E 6BT, UK

c. CNRS Unité 8118, Université Paris Descartes, 75006 Paris, France

\section{Supplementary Data}

The experiments described here relate to the synthesis of the model compound $\mathbf{1 5}$ which were carried out as optimisation procedures for the synthesis of our target molecule 8. The mild alkaline hydrolysis of compound $\mathbf{1 9}$ and details of neurophysiological experiments with $\mathbf{8}$ including interpretation for some of the results are also reported here. Compounds are referred to by the numbering system in the main text. UV-vis spectra for progressive photolysis of $\mathbf{8}$ and $\mathbf{1 5}$ are also shown.

Experimental Details

Procedures related to Scheme 2.

\section{1-[2-(tert-Butoxycarbonylamino)acetyl]-4-methoxyindoline (9)}

To a solution of 4-methoxyindoline $(3.73 \mathrm{~g}, 25 \mathrm{mmol}$; prepared as previously described $\left.^{1}\right)$ in dry $\mathrm{MeCN}(30 \mathrm{~mL})$ was added $N$-tert-BOC-glycine (4.44 g, $\left.25.3 \mathrm{mmol}\right)$ and 1-(3-dimethylaminopropyl)-3-ethylcarbodiimide hydrochloride (5.27 g, 27.5 mmol) and the mixture was stirred under nitrogen at $\mathrm{rt}$ overnight. The solvent was evaporated and the residue was taken up in EtOAc $(80 \mathrm{~mL})$, washed with $1 \mathrm{M}$ aq. $\mathrm{HCl}$, aq. $\mathrm{NaHCO}_{3}$ and brine, dried and evaporated to give $9(6.43 \mathrm{~g}, 84 \%)$ as white crystals, mp $146-148{ }^{\circ} \mathrm{C}$ (EtOAc-hexanes); ${ }^{1} \mathrm{H}$ NMR $(600 \mathrm{MHz}) \delta 7.81(\mathrm{~d}, J=8.2$ $\mathrm{Hz}, 1 \mathrm{H}), 7.19$ (t, $J=8.2 \mathrm{~Hz}, 1 \mathrm{H}), 6.61(\mathrm{~d}, J=8.2 \mathrm{~Hz}, 1 \mathrm{H}), 5.55$ (br s, 1H), 4.03 (s, 
2H), $4.01(\mathrm{t}, J=8.5 \mathrm{~Hz}, 2 \mathrm{H}), 3.84(\mathrm{~s}, 3 \mathrm{H}), 3.14(\mathrm{t}, J=8.5 \mathrm{~Hz}, 2 \mathrm{H}), 1.47(\mathrm{~s}, 9 \mathrm{H})$. Anal. Calcd for $\mathrm{C}_{16} \mathrm{H}_{22} \mathrm{~N}_{2} \mathrm{O}_{4}$ : C, 62.73; H, 7.24; N, 9.14. Found: C, 62.60; H, 7.26; N, 9.10 .

\section{1-[2-(Di-tert-butoxycarbonylamino)acetyl]-4-methoxyindoline (10)}

A solution of $9(4.60 \mathrm{~g}, 15 \mathrm{mmol})$ in a mixture of dry $\mathrm{CH}_{2} \mathrm{Cl}_{2}(75 \mathrm{~mL})$ and dry $\mathrm{Et}_{3} \mathrm{~N}$ $(150 \mathrm{~mL})$ was treated with di-tert-butyl dicarbonate $(9.82 \mathrm{~g}, 45 \mathrm{mmol})$ and DMAP (183 mg, $1.5 \mathrm{mmol}$ ) and refluxed under nitrogen for $4 \mathrm{~h}$. The solvents were evaporated and the residue diluted with EtOAc $(80 \mathrm{~mL})$ and washed successively with $1 \mathrm{M}$ aq. $\mathrm{KHSO}_{4}$, saturated aq. $\mathrm{NaHCO}_{3}$ and brine, dried and evaporated to give $\mathbf{1 0}$ (4.59 g, 75\%) as white crystals, mp 176-178 ${ }^{\circ} \mathrm{C}$ (EtOAc-hexanes); ${ }^{1} \mathrm{H}$ NMR (600 MHz) $\delta 7.84(\mathrm{~d}, J=8.2 \mathrm{~Hz}, 1 \mathrm{H}), 7.16(\mathrm{t}, J=8.2 \mathrm{~Hz}, 1 \mathrm{H}), 6.58(\mathrm{~d}, J=8.2 \mathrm{~Hz}, 1 \mathrm{H})$, $4.45(\mathrm{~s}, 2 \mathrm{H}), 4.07$ (t, $J=8.2 \mathrm{~Hz}, 2 \mathrm{H}), 3.83(\mathrm{~s}, 3 \mathrm{H}), 3.14(\mathrm{t}, J=8.2 \mathrm{~Hz}, 2 \mathrm{H}), 1.51(\mathrm{~s}$, 18H). Anal. Calcd for $\mathrm{C}_{21} \mathrm{H}_{30} \mathrm{~N}_{2} \mathrm{O}_{6}: \mathrm{C}, 62.05 ; \mathrm{H}, 7.44 ; \mathrm{N}, 6.89$. Found: $\mathrm{C}, 62.21 ; \mathrm{H}$, $7.51 ; \mathrm{N}, 6.80$.

\section{1-[2-(tert-Butoxycarbonylnitroamino)acetyl]-4-methoxy-7-nitroindoline (11)}

A solution of $10(2.03 \mathrm{~g}, 5 \mathrm{mmol})$ in a mixture of $\mathrm{CH}_{2} \mathrm{Cl}_{2}(50 \mathrm{~mL})$ and acetic anhydride $(75 \mathrm{~mL})$ was treated with copper nitrate hemipentahydrate (1.28 g, 5.5 mmol) and stirred at $\mathrm{rt}$ overnight. The solution was concentrated and the residue was re-evaporated from toluene, diluted with EtOAc $(50 \mathrm{~mL})$ and washed with saturated aq. $\mathrm{NaHCO}_{3}$ and brine, dried and evaporated to give brown viscous oil. The product was dissolved in $\mathrm{CH}_{2} \mathrm{Cl}_{2}(50 \mathrm{~mL})$, treated with $1 \mathrm{M}$ TFA in $\mathrm{CH}_{2} \mathrm{Cl}_{2}(7.5 \mathrm{~mL}, 7.5$ mmol) and stirred at $\mathrm{rt}$ overnight. The solvent was evaporated and the residue was taken up in EtOAc $(50 \mathrm{~mL})$, washed with saturated aq. $\mathrm{NaHCO}_{3}$ and brine, dried and evaporated to give brown viscous oil. Flash chromatography [EtOAc-hexanes $(2: 3)$ ] afforded two major products. The first eluted material was a yellow solid which after recrystallisation gave $11(0.297 \mathrm{~g}, 37 \%)$ as pale yellow crystals mp 137-139 ${ }^{\circ} \mathrm{C}$ (EtOAc-hexanes), ${ }^{1} \mathrm{H}$ NMR $(800 \mathrm{MHz}) \delta 7.81(\mathrm{~d}, J=9.0 \mathrm{~Hz}, 1 \mathrm{H}), 6.68(\mathrm{~d}, J=9.0 \mathrm{~Hz}$, 1H), $4.87(\mathrm{~s}, 2 \mathrm{H}), 4.32(\mathrm{t}, J=8.1 \mathrm{~Hz}, 2 \mathrm{H}), 3.93(\mathrm{~s}, 3 \mathrm{H}), 3.17$ (t, $J=8.1 \mathrm{~Hz}, 2 \mathrm{H}), 1.59$ (s, 9H). Anal. Calcd for $\mathrm{C}_{16} \mathrm{H}_{20} \mathrm{~N}_{4} \mathrm{O}_{8}: \mathrm{C}, 48.49 ; \mathrm{H}, 5.09 ; \mathrm{N}, 14.13$. Found: C, 48.74; $\mathrm{H}, 5.08 ; \mathrm{N}, 14.13$.

The second eluted material and the mother liquor from the first fraction were 
combined to pale yellow foam $(0.49 \mathrm{~g})$. The ${ }^{1} \mathrm{H}$ NMR spectrum indicated that that product was mostly 1-[2-(tert-butoxycarbonylamino)acetyl]-4-methoxy-7-nitroindoline contaminated with the 5-nitro isomer but the material was not further characterised.

\section{Procedures related to Scheme 3.}

\section{1-(2-Bromoacetyl)-4-methoxyindoline (12)}

A solution of 4-methoxyindoline $\left(1.49 \mathrm{~g}, 10 \mathrm{mmol}\right.$; prepared as previously described $\left.{ }^{1}\right)$ in dry $\mathrm{MeCN}(50 \mathrm{~mL})$ was treated with 2-bromoacetic acid (1.67 g, $12 \mathrm{mmol})$, followed by 1-(3-dimethylaminopropyl)-3-ethylcarbodiimide hydrochloride (2.11 g, $11 \mathrm{mmol}$ ) and the mixture was stirred at $\mathrm{rt}$ under nitrogen overnight. The solvent was evaporated and the residue was taken up in EtOAc $(50 \mathrm{~mL})$ washed with dilute aq. $\mathrm{HCl}$, saturated aq. $\mathrm{NaHCO}_{3}$ and brine, dried and evaporated to pale crystals. Recrystallisation (EtOAc-hexanes) followed by flash chromatography [EtOAchexanes (3:7)] of the mother liquor gave 12 (2.28 g, 84\%) as white crystals, mp 141$143{ }^{\circ} \mathrm{C}$ (EtOAc-hexanes); ${ }^{1} \mathrm{H}$ NMR $(800 \mathrm{MHz}) \delta 7.83(\mathrm{~d}, J=8.1 \mathrm{~Hz}, 1 \mathrm{H}), 7.20(\mathrm{t}, J=$ $8.1 \mathrm{~Hz}, 2 \mathrm{H}), 6.63(\mathrm{~d}, J=8.1 \mathrm{~Hz}, 1 \mathrm{H}), 4.20$ and $4.18(2 \times \mathrm{t}, J=8.2 \mathrm{~Hz}, 2 \mathrm{H}$, rotamers $)$, $4.15(\mathrm{~s}, 2 \mathrm{H}), 3.84(\mathrm{~s}, 3 \mathrm{H}), 3.16(\mathrm{t}, J=8.2 \mathrm{~Hz}, 2 \mathrm{H})$. Anal. Calcd for $\mathrm{C}_{11} \mathrm{H}_{12} \mathrm{NO}_{2} \mathrm{Br}: \mathrm{C}$, 48.91; H, 4.48; N, 5.18. Found: C, 48.83; H, 4.52; N, 5.18.

\section{1-(2-Azidoacetyl)-4-methoxyindoline (13)}

To a solution of $12(2.16 \mathrm{~g}, 8 \mathrm{mmol})$ in dry DMF $(60 \mathrm{~mL})$ was added $\mathrm{NaN}_{3}(1.56 \mathrm{~g}$, $24 \mathrm{mmol}$ ) and the mixture was stirred at $\mathrm{rt}$ overnight. The solvent was removed under reduced pressure and the residue was diluted with EtOAc $(80 \mathrm{~mL})$, washed with water and brine, dried and evaporated to give 13 as a white crystals (1.78 g, 96\%), mp 149$151{ }^{\circ} \mathrm{C}\left(\mathrm{Et}_{2} \mathrm{O}-\right.$ hexanes $) ;{ }^{1} \mathrm{H}$ NMR $(600 \mathrm{MHz}) \delta 7.86(\mathrm{~d}, J=8.2 \mathrm{~Hz}, 1 \mathrm{H}), 7.20(\mathrm{t}, J=$ $8.2 \mathrm{~Hz}, 2 \mathrm{H}), 6.62(\mathrm{~d}, J=8.2 \mathrm{~Hz}, 1 \mathrm{H}), 4.00(\mathrm{t}, J=8.5 \mathrm{~Hz}, 2 \mathrm{H}), 3.97$ (s, 2H), 3.84 (s, $3 \mathrm{H}), 3.15(\mathrm{t}, J=8.5 \mathrm{~Hz}, 2 \mathrm{H})$. Anal. Calcd for $\mathrm{C}_{11} \mathrm{H}_{12} \mathrm{~N}_{4} \mathrm{O}_{2}: \mathrm{C}, 56.89 ; \mathrm{H}, 5.21 ; \mathrm{N}$, 24.11. Found: C, 57.14; H, 5.19; N, 24.39.

\section{1-(2-Azidoacetyl)-4-methoxy-7-nitroindoline (14)}

To a solution of 13 (464 mg, $2 \mathrm{mmol})$ in dry $\mathrm{MeCN}(20 \mathrm{~mL})$ was added acetic 
anhydride (2.04 g, $20 \mathrm{mmol}), \mathrm{NaNO}_{3}(340 \mathrm{mg}, 4 \mathrm{mmol})$ and scandium triflate ${ }^{2}$ (551 $\mathrm{mg}, 1.2 \mathrm{mmol})$. The mixture was stirred at $\mathrm{rt}$ for $22 \mathrm{~h}$, diluted with EtOAc $(80 \mathrm{~mL})$ and washed with saturated aq. $\mathrm{NaHCO}_{3}$ and brine, dried and evaporated. Repeated flash chromatography [EtOAc-hexanes (2:3)] gave 14 (416 mg, 75\%) as pale crystals, mp $124-125{ }^{\circ} \mathrm{C}($ EtOAc-hexanes $) ;{ }^{1} \mathrm{H}$ NMR $(600 \mathrm{MHz}) \delta 7.82(\mathrm{~d}, J=9.0 \mathrm{~Hz}, 1 \mathrm{H})$, $6.69(\mathrm{~d}, J=9.0 \mathrm{~Hz}, 1 \mathrm{H}), 4.21(\mathrm{t}, J=8.0 \mathrm{~Hz}, 2 \mathrm{H}), 4.03(\mathrm{~s}, 2 \mathrm{H}), 3.93(\mathrm{~s}, 3 \mathrm{H}), 3.12(\mathrm{t}, J$ $=8.0 \mathrm{~Hz}, 2 \mathrm{H})$. Anal. Calcd for $\mathrm{C}_{11} \mathrm{H}_{11} \mathrm{~N}_{5} \mathrm{O}_{4}: \mathrm{C}, 47.66 ; \mathrm{H}, 4.00 ; \mathrm{N}, 25.25$. Found: $\mathrm{C}$, 47.66; H, 3.98; N, 25.52 .

\section{1-(2-Aminoacetyl)-4-methoxy-7-nitroindoline (15)}

To a solution of $14(227 \mathrm{mg}, 1 \mathrm{mmol})$ in dry DMF $(10 \mathrm{~mL})$ was added water $(1.1 \mathrm{~mL})$ and triphenylphosphine $(1.84 \mathrm{~g}, 7 \mathrm{mmol})$ and the mixture stirred at $\mathrm{rt}$ overnight. TLC (EtOAc-hexanes (2:3)] indicated that all starting material was consumed. The solvent was evaporated under reduced pressure and the residue was dissolved in water (50 $\mathrm{mL}$ ), the $\mathrm{pH}$ was lowered from 9.5 to 1.3 with $1 \mathrm{M}$ aq. $\mathrm{HCl}$ and the solution was washed with $\mathrm{Et}_{2} \mathrm{O}(4 \times 40 \mathrm{~mL})$. The aqueous phase was then carefully basified to $\mathrm{pH}$ 10.5 with $1 \mathrm{M}$ aq. $\mathrm{NaOH}$ and extracted with $\mathrm{CHCl}_{3}(3 \times 30 \mathrm{~mL})$. The combined organic phases from the basic extraction were dried and evaporated to give pale yellow crystals $(180 \mathrm{mg}, 64 \%) ;{ }^{1} \mathrm{H}$ NMR $\left(600 \mathrm{MHz}, \mathrm{CDCl}_{3}\right) \delta 7.75(\mathrm{~d}, J=9.0 \mathrm{~Hz}$, 1H), 6.69 (d, $J=9.0 \mathrm{~Hz}, 1 \mathrm{H}), 4.17(\mathrm{t}, J=8.1 \mathrm{~Hz}, 2 \mathrm{H}), 3.92$ (s, 3H), 3.59 (s, 2H), 3.10 (t, $J=8.1 \mathrm{~Hz}, 2 \mathrm{H}), 1.64(\mathrm{~s}, 2 \mathrm{H})$. The material was dissolved in $\mathrm{MeOH}(8 \mathrm{~mL})$, diluted with water $(40 \mathrm{~mL})$ and the $\mathrm{pH}$ was carefully lowered to 6.68 with $1 \mathrm{M}$ aq. $\mathrm{HCl}$. After lyophilisation the residual powder was dissolved in water $(20 \mathrm{~mL})$, passed through a $0.2 \mu \mathrm{m}$ membrane filter and lyophilised again to give $15(183 \mathrm{mg}, 64 \%)$ as its hydrochloride salt; ${ }^{1} \mathrm{H}$ NMR (600 MHz, $\mathrm{D}_{2} \mathrm{O}$, acetone ref.) $\delta 7.87(\mathrm{~d}, J=9.1 \mathrm{~Hz}, 1 \mathrm{H})$, $6.97(\mathrm{~d}, J=9.1 \mathrm{~Hz}, 1 \mathrm{H}), 4.26(\mathrm{t}, J=7.9 \mathrm{~Hz}, 2 \mathrm{H}), 4.14(\mathrm{~s}, 2 \mathrm{H}), 3.97(\mathrm{~s}, 3 \mathrm{H}), 3.15(\mathrm{t}, J$ $=7.9 \mathrm{~Hz}, 2 \mathrm{H})$. HRMS (ES): Calcd for $\left(\mathrm{C}_{11} \mathrm{H}_{13} \mathrm{~N}_{3} \mathrm{O}_{4}+\mathrm{H}\right)^{+}$, 252.0984. Found, 252.0979 .

Procedure related to Scheme 4

\section{Alkaline hydrolysis of 19}

A solution of 19 (274 mg, $0.65 \mathrm{mmol})$ in $\mathrm{MeOH}(50 \mathrm{~mL})$, water $(5 \mathrm{~mL})$ and $1 \mathrm{M}$ aq. 
$\mathrm{NaOH}(1.56 \mathrm{~mL}, 1.56 \mathrm{mmol})$ was stirred at rt for $2 \mathrm{~min}$, quenched with $1 \mathrm{M}$ citric acid (3.3 mL) and concentrated to $\sim 10 \mathrm{~mL}$. The solution was diluted with water $(20 \mathrm{~mL})$, washed with EtOAc $(3 \times 30 \mathrm{~mL})$ and the combined organic washings were washed with saturated aq. $\mathrm{NaHCO}_{3}$ and brine, dried and evaporated to a brown viscous oil (292 mg) TLC [MeOH-EtOAc (1:24)] and UV-vis spectroscopy showed evidence that in addition to hydrolysis of the acetyl groups, amide bond hydrolysis to the corresponding nitroindoline, also took place. The latter process was apparent from the appearance of a new absorption band at $425 \mathrm{~nm}$. For comparison, 4-methoxy-7nitroindoline has $\lambda_{\max }[\mathrm{EtOH}-25 \mathrm{mM}$ Na phosphate, $\mathrm{pH} 7.0(1: 24)] / \mathrm{nm}\left(\varepsilon / \mathrm{M}^{-1} \mathrm{~cm}^{-1}\right)$ 247 (11940), 317 (9450), 425 (4200).

In a separate experiment a solution $19(24.4 \mathrm{mg}, 58 \mu \mathrm{mol})$ in redistilled DMSO (3 $\mathrm{mL})$ was diluted with $25 \mathrm{mM}$ Na phosphate buffer, $\mathrm{pH} 7.0(27 \mathrm{~mL})$ and stirred at $\mathrm{rt}$ for $23 \mathrm{~h}$. The solution was extracted with EtOAc $(3 \times 20 \mathrm{~mL})$ and the combined organic phases were dried and evaporated, dissolved in EtOH $(10 \mathrm{~mL})$ and diluted with water $(20 \mathrm{~mL})$. UV-vis spectroscopy $\left(\lambda_{\max } 425 \mathrm{~nm}\right)$ detected $\sim 10 \%$ amide bond hydrolysis. 
Progressive photolysis spectra for compounds (8) and (15).
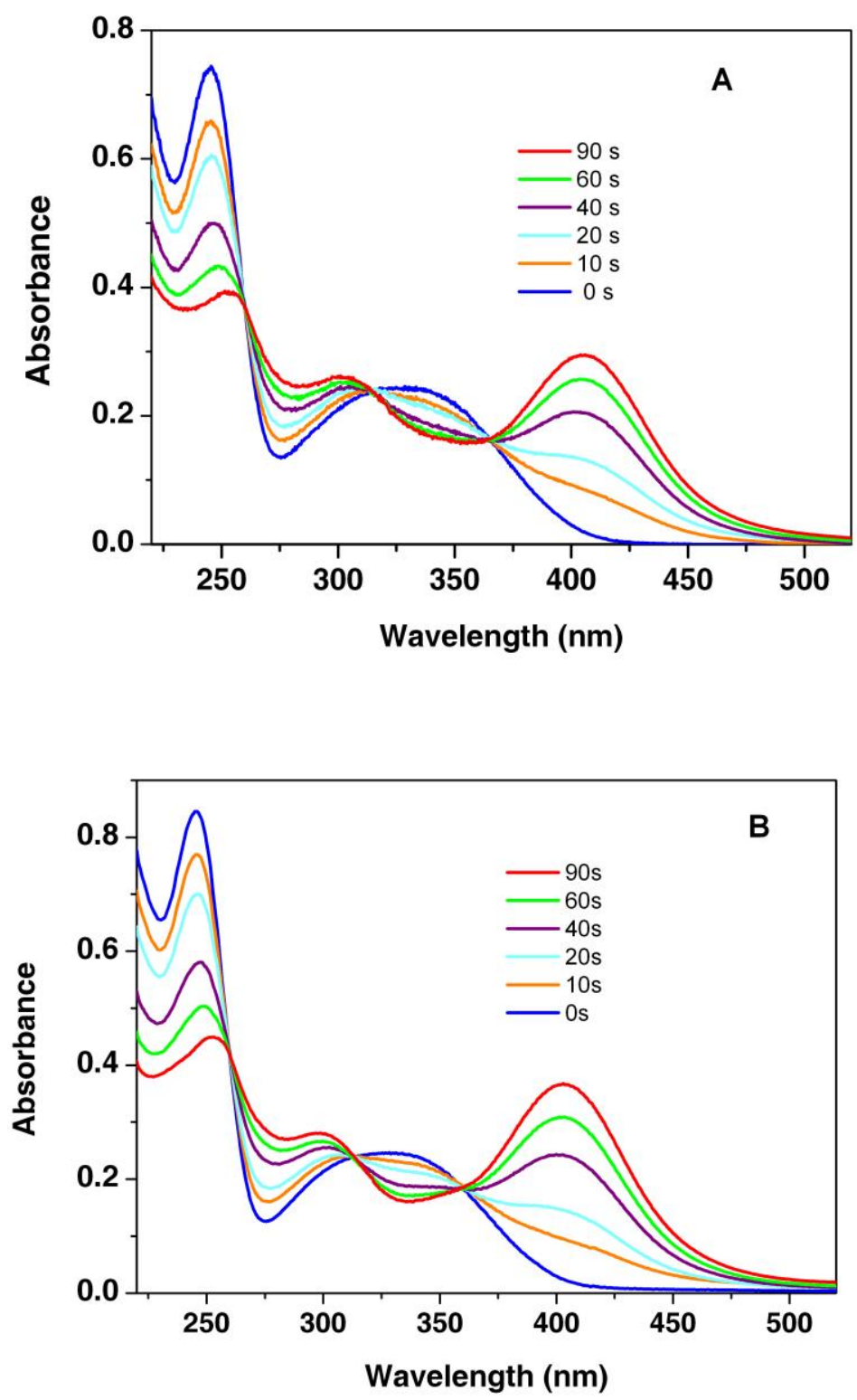

Figure S1. Panels (A) and (B) are spectra recorded after the irradiation times shown in the key of each panel for solutions of 8 and 15 respectively, under conditions as specified in the main text.

Experimental details relating to these spectra appear in the main text. 


\section{Neurophysiological experiments and photolysis of DPNI-glycine (8)}

Sprague-Dawley rats 9 days old were anaesthetised and decapitated in accordance with Institutional guidelines. Rats were provided by Janvier (Sterthevin, France) and subsequently housed at the central animal house at Université Paris Descartes (Centre St Pères, approval number A-750607), approved by the Prefecture de Police following inspection by Veterinary Services of the City of Paris, and representatives of the French Ministry for Research and the Ministry for Health, in agreement with the European Directive 86/609/EEC regarding the protection of animals used for experimental and other scientific purposes. Experimental procedures were approved by the Directorate of Paris Veterinary Services, by the scientific committee of the central animal house of Université Paris Descartes (Centre St Pères) as well as by the ethical committee for animal experimentation of Université Paris Descartes.

A ventral laminectomy was performed in ice-cold solution and mid-thoracic to lumbar segments of the cord were extracted, cleared of connective tissue and glued to an agar block with tissue glue (Vetbond; WPI Scientific Instruments). The block was fixed vertically on the platform of a vibratome, and transverse slices were cut at a thickness of $350 \mu \mathrm{m}$ from the lower lumbar region (L2-L5 segments). The slicing solution was kept ice-cold and contained (in $\mathrm{mM}$ ): $130 \mathrm{~K}$-gluconate, $15 \mathrm{KCl}, 0.05$ EGTA, 20 HEPES, and 25 glucose, $\mathrm{pH}$ adjusted to 7.4 with $\mathrm{NaOH}$. Kynurenic acid ( $3 \mathrm{mM})$ was added to the slicing solution to protect the tissue from glutamate excitotoxicity.

\section{Electrophysiological recordings}

To minimise usage of the DPNI-glycine, uncaging was done in HEPES-buffered saline without solution flow in the bath. Composition (mM) $135 \mathrm{NaCl}, 4 \mathrm{KCl}, 2$ $\mathrm{NaHCO}_{3}, 25$ glucose, $2 \mathrm{CaCl}_{2}, 2 \mathrm{MgCl}_{2}$ and 10 HEPES, pH 7.4. $2 \mathrm{mM} \mathrm{NaHCO}$ was present to help maintain intracellular pH. TTX 0.2 or $0.5 \mu \mathrm{M}$, CNQX or NBQX $2 \mu \mathrm{M}$ and AP5 $20 \mu \mathrm{M}$ were added to block excitation and ionotropic glutamate receptors. Slices were transferred to a $0.5 \mathrm{~mL}$ recording chamber in HEPES-buffered saline and initially perfused at a flow rate of $1.5 \mathrm{~mL} / \mathrm{min}$. $\mathrm{O}_{2}$ was blown over the surface of the bath to improve tissue survival and facilitate mixing. DPNI-glycine $\mathbf{8}$ was added from $20 \mathrm{mM}$ stock solutions once a recording was obtained and the solution flow stopped. 
Drugs were obtained from Tocris (Bristol, U.K.) and chemicals from Sigma (Poole, U.K.).

The cells were recorded in the whole-cell configuration of the patch clamp technique, with an Axopatch 200B amplifier (Molecular Devices, Sunnyvale, CA) at room temperature. Pipettes were pulled from thick-walled borosilicate glass (GC150F; Harvard Apparatus) and fire polished to a final resistance of 1-1.5 $\mathrm{M} \Omega$. Internal solution contained (in $\mathrm{mM}$ ): $140 \mathrm{CsCl}, 4 \mathrm{NaCl}, 1 \mathrm{MgCl}_{2}, 0.5 \mathrm{CaCl}_{2}, 5$ EGTA, 10 HEPES, 2 MgATP, 3 mM QX-314 (lidocaine $N$-ethyl bromide), pH 7.3. Alexa 488 (20 or $40 \mu \mathrm{M}$ ) was included to obtain cell morphology. Series resistance (between 4 and $10 \mathrm{M} \Omega$ ) was monitored by applying $20 \mathrm{~ms}$ long hyperpolarizing pulses and it was compensated by $60-80 \%$. The experiment was abandoned if series resistance increased by more than $20 \%$. Given the typical motoneuron whole cell capacitance of approximately $200 \mathrm{pF}$, this corresponds to a corner frequency between 0.2 and 0.8 $\mathrm{kHz}$.

Data acquisition was with a P1401 interface (CED Cambridge UK) and WinWCP software (written by Dr John Dempster, University of Strathclyde).

Laser-induced photorelease of glycine from DPNI-glycine.

The custom experimental microscope used for photolysis of DPNI-glycine 8 has been described in full. ${ }^{3}$ Briefly, the collimated output of a $405 \mathrm{~nm}$ fiber-coupled laser (Iflex 2000, Point Source, Southampton, UK) was expanded to $90 \%$ of the back aperture of a $63 \times, 0.9$ NA Leica water-dipping objective. The point spread function of the laser at the focus had a Gaussian profile, with $1 / \mathrm{e}^{2}$ radius $=0.57$ $\mu \mathrm{m}$ in the focal plane and $1.9 \mu \mathrm{m}$ axially. The light pulse entering the objective was monitored with a photodiode and recorded. The frequency, duration and intensity of laser pulses were set with a Digitimer D4030 (Digitimer, Welwyn, UK) and analogue electronics. Transmitted illumination was with a white LED through a 0.9 NA darkfield condenser. Epifluorescence illumination was with a blue LED (excitation 470/30 $\mathrm{nm}$ ). Light emitted from Alexa 488 was filtered $530 / 40 \mathrm{~nm}$, collected by an EMCCD camera (Andor Ixon, Belfast, UK) and images were acquired with Andor software. Once the cell was filled and a dendritic field selected, the solution flow was turned off, DPNI-glycine was added 
directly to the bath to give concentrations up to $3 \mathrm{mM}$ and after mixing was allowed to equilibrate for at least $5 \mathrm{~min}$ before photolysis. Laser flashes were usually of $200 \mu$ s duration, repeated at up to $0.2 \mathrm{~Hz}$ and with intensities at the preparation up to $2 \mathrm{~mW}$.

Interactions between DPNI-glycine and glycine receptors

The possibility that DPNI-glycine 8 might itself interfere with glycine synaptic transmission was tested by comparing the amplitude of spontaneous glycinergic synaptic events in the absence of $\mathbf{8}$ or its presence in the bath at $3 \mathrm{mM}$ concentration. An example of spontaneous glycinergic currents before and during application of 3 $\mathrm{mM}$ DPNI-glycine is shown in Figure S2A and S2B respectively. There is no difference in the average amplitude of synaptic response with or without DPNIglycine (from $89 \pm 17$ to $87 \pm 17 \mathrm{pA}, \mathrm{n}=12$ cells, Figure S2D). Similarly, the risetime is not affected by the presence of the caged compound $(1.1 \pm 0.1$ and $1.2 \pm 0.1$ $\mathrm{ms}, \mathrm{n}=12$, Figure $\mathrm{S} 2 \mathrm{C}$ ), indicating that there is very little interaction between glycine receptors and the caged glycine before photolysis.

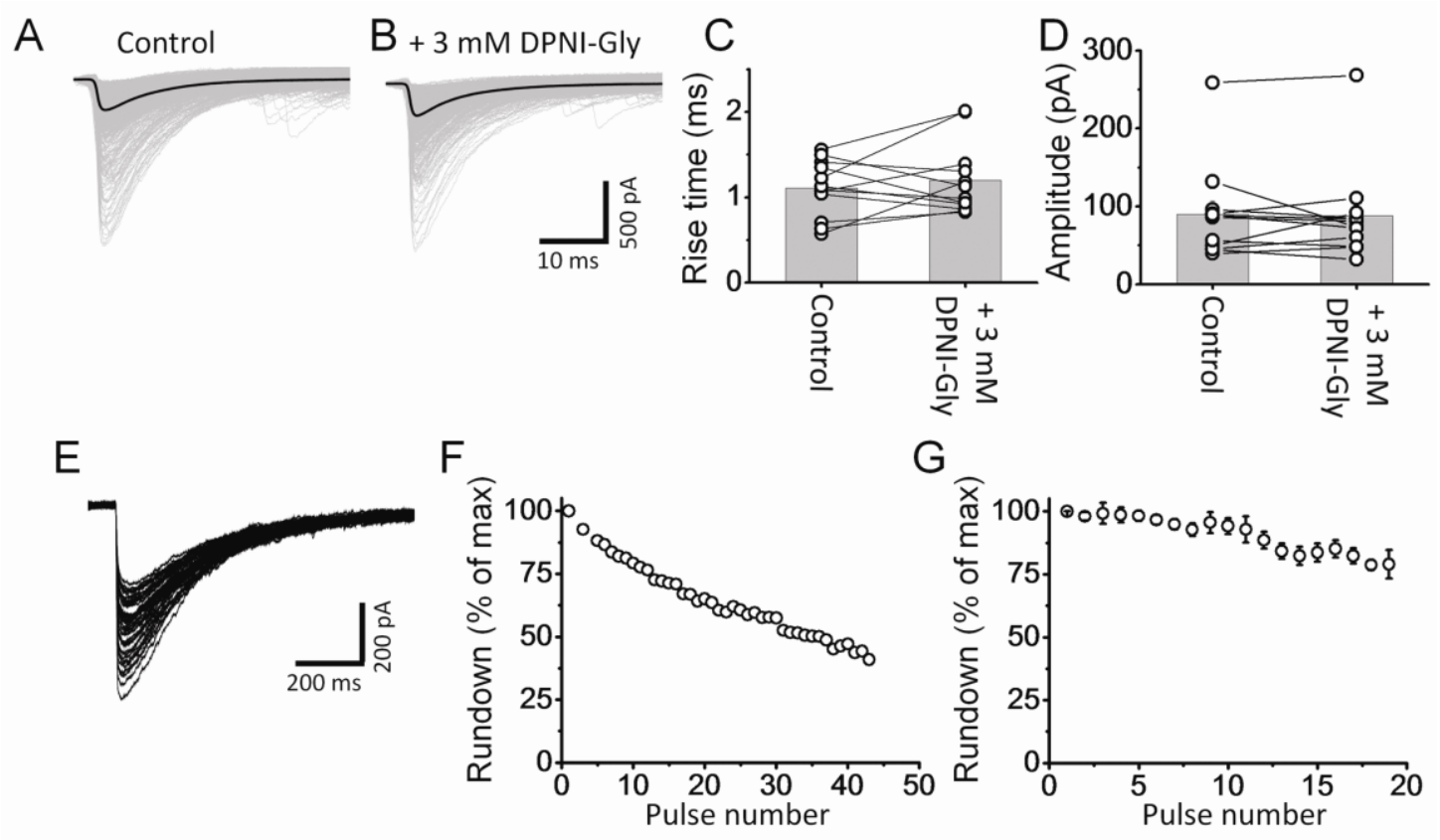


Figure S2. Testing for interference of photolysis of DPNI-glycine $\mathbf{8}$ with glycine receptors. (A-D) $3 \mathrm{mM}$ DPNI-glycine has no effect on synaptic responses. (A) Superimposed spontaneous glycine synaptic responses and the mean before addition of DPNI-glycine. (B) Superimposed records on the same scale in the presence of 3 mM DPNI-glycine. (C, D) Data from 12 neurons showing no systematic effect of 3 $\mathrm{mM}$ DPNI-glycine on the $20-80 \%$ rise-time (C) or amplitude (D) of spontaneous glycine synaptic responses. (E-G) Repeated photolysis pulses at the same location. (E, F) Progressive decrease in the response amplitude during 45 responses to $1 \mathrm{~ms}$ pulses of $4.8 \mathrm{~mW}$ at $0.2 \mathrm{~Hz}$ superimposed (E) and plotted against pulse number (F). (G) Data obtained in a similar experiment with briefer $(0.2 \mathrm{~ms})$ higher intensity pulses $(7.2 \mathrm{~mW}$ at the objective) showing approx. 20\% rundown. Both pulse protocols produce maximal photolysis of DPNI-glycine.

Repeated photorelease at the same location resulted in a progressive decrease of the peak amplitude of glycine-evoked currents. The run down was very severe for long (1 $\mathrm{ms}, 4.8 \mathrm{~mW}$ ) pulses, as shown in Figure S2E, where 45 consecutive responses progressively decreased in size to $\sim 40 \%$ of the starting value (Figure S2F). The effect is less pronounced when $200 \mu$ s pulses $(7.2 \mathrm{~mW})$ are used, as shown by the $\sim 20 \%$ run down after 20 pulses (Figure S2G, average of 12 experiments), but was present for all intensities and pulse durations tested. The laser pulses had sufficient energy to produce complete photolysis of DPNI-glycine in the irradiated volume. Experiments to test the origin of the rundown suggested that it was due to the photolysis reaction of DPNI-glycine. It could not be attributed to the presence of residual tris(2carboxyethyl)phosphine oxide present in the solution (see Experimental section 4.8), and was unaffected by adding ascorbate or glutathione to scavenge reactive byproducts (data not shown). Similar rundown has not been seen previously with nitroindoline-caged amino acids, neither with MNI-glutamate nor DPNI-GABA. Its origin may be associated with the $68-69 \%$ glycine release obtained on photolysis of DPNI-glycine, contrasting with the full stoichiometric conversions of MNI-glutamate ${ }^{4}$ and DPNI-GABA ${ }^{5}$ reported previously. 


\section{References}

1. Papageorgiou, G.; Corrie, J.E.T. Tetrahedron 2000, 56, 8197-8205.

2. Kawada, A.; Takeda, S.; Yamashita, K.; Abe, H.; Harayama, T. Chem. Pharm. Bull. 2002, 50, 1060-1065

3. Trigo, F. F.; Corrie, J. E. T.; Ogden, D. J. Neurosci. Methods 2009, 180, 9-21.

4. Papageorgiou, G.; Corrie, J. E. T. Tetrahedron 2000, 56, 8197-8205.

5. Papageorgiou, G.; Corrie, J. E. T. Tetrahedron 2007, 63, 9668-9676. 